Article

\title{
A Critical Evaluation on the Role of Aerodynamic and Canopy-Surface Conductance Parameterization in SEB and SVAT Models for Simulating Evapotranspiration: A Case Study in the Upper Biebrza National Park Wetland in Poland
}

\author{
Kaniska Mallick ${ }^{1, *(\mathbb{D})}$, Loise Wandera ${ }^{1,2, *}$ (D) Nishan Bhattarai ${ }^{3}\left(\mathbb{D}\right.$, Renaud Hostache $^{1}(\mathbb{D}$, \\ Malgorzata Kleniewska ${ }^{4}$ and Jaroslaw Chormanski ${ }^{4}$ (D) \\ 1 Remote Sensing and Natural Resources Modeling, Department ERIN, Luxembourg Institute of Science and \\ Technology (LIST), 4422 Belvaux, Luxembourg; renaud.hostache@list.lu \\ 2 Department of Water Resources, ITC, University of Twente, 7522 NB Enschede, The Netherlands \\ 3 School for Environment and Sustainability, University of Michigan, Ann Arbor, MI 48109, USA; \\ nbhattar@umich.edu \\ 4 Department of Hydraulic Engineering, Faculty of Civil and Environmental Engineering, Warsaw University \\ of Life Sciences, Nowoursynowska 166, 02-787 Warsaw, Poland; malgorzata_kleniewska@sggw.pl (M.K.); \\ j.chormanski@levis.sggw.pl (J.C.) \\ * Correspondence: kaniska.mallick@list.lu (K.M.); 1.n.n.wandera@utwente.nl (L.W.); \\ Tel.: +352-671-521-057 (K.M.)
}

Received: 28 September 2018; Accepted: 23 November 2018; Published: 28 November 2018

\begin{abstract}
Evapotranspiration (ET) estimation through the surface energy balance (SEB) and soil-vegetation-atmosphere-transfer (SVAT) models are uncertain due to the empirical parameterizations of the aerodynamic and canopy-substrate conductances $\left(g_{A}\right.$ and $\left.g_{S}\right)$ for heat and water vapor transfers. This study critically assessed the impact of conductance parameterizations on ET simulation using three structurally different SEB and SVAT models for an ecologically important North-Eastern European wetland, Upper Biebrza National Park (UBNP) in two consecutive years 2015 and 2016. A pronounced ET underestimation (mean bias -0.48 to $-0.68 \mathrm{~mm} \mathrm{day}^{-1}$ ) in SEBS (Surface Energy Balance System) was associated with an overestimation of $\mathrm{g}_{\mathrm{A}}$ due to uncertain parameterization of momentum roughness length and bare soil's excess resistance to heat transfer $\left(\mathrm{kB}^{-1}\right)$ under low vegetation cover. The systematic ET overestimation $\left(0.65-0.80 \mathrm{~mm}\right.$ day $\left.^{-1}\right)$ in SCOPE (Soil Canopy Observation, Photochemistry and Energy fluxes) was attributed to the overestimation of both the conductances. Conductance parameterizations in SEBS and SCOPE appeared to be very sensitive to the general ecohydrological conditions, with a tendency of overestimating $\mathrm{g}_{\mathrm{A}}\left(\mathrm{g}_{\mathrm{S}}\right)$ under humid (arid) conditions. Low ET bias in the analytical STIC (Surface Temperature Initiated Closure) model as compared to SEBS/SCOPE indicated the critical need for calibration-free conductance parameterizations for improved ET estimation.
\end{abstract}

Keywords: surface energy balance; SVAT; aerodynamic conductance; canopy-surface conductance; evapotranspiration; wetland; Biebrza National Park

\section{Introduction}

Evapotranspiration (ET) (or latent heat flux, $\lambda \mathrm{E}$ ) monitoring in the wetlands are important for evaluating the hydrological budget, estimating groundwater discharge, quantifying seasonal water availability, and tracking as well as anticipating drought conditions [1]. Among the hydrological 
variables, ET is the most reliable indicator of hydrological recovery [2,3], and the difference between annual precipitation $(\mathrm{P})$ and ET is a measure of the wetland health [3]. The biogeochemical cycling, wetland vigour and ecosystem services are largely impaired due to the evaporative depletion of the wetlands [4-6]. Therefore, a detailed knowledge of wetland ET is crucial for predicting and monitoring the functioning of these ecosystems or for restoring the transformed wetlands to their original condition [7].

Among the range of techniques used to measure wetland ET (e.g., lysimetric, Bowen-ratio energy balance and the eddy-covariance), eddy covariance (EC) is the most promising for continuous monitoring of ET. However, it is hindered by a number of technical, economic and environmental factors. For instance, the EC method is resource intensive [8], and such instrumentation sometimes suffer due to extended periods of non-operation [8]. The EC sensors can malfunction when their measurement paths are obstructed by water droplets, water films, snow/ice particles, or other solids or liquids that interfere with the transmission or reception of the sensor signals (as described in [9]). Therefore, it is practical to conduct short-term studies to test and evaluate alternative approaches e.g., the Surface Energy Balance (SEB) or the Soil-Vegetation-Atmosphere-Transfer (SVAT) models that can be eventually used to estimate ET for the other time periods [8,10]. With the availability of uninterrupted measurement of meteorological, radiative, and hydrological variables (e.g., shortwave and longwave radiation components, air temperature, relative humidity, wind speed, soil moisture, and precipitation), ET simulation through SEB/SVAT models can be a cost-effective solution and can also fill the gaps in missing surface energy balance measurements to provide continuous records. Additionally, ET simulation through SEB/SVAT models can provide insight towards the impacts of ecohydrological and environmental anomalies on the evaporative depletion in the wetlands, and understanding the effects of soil moisture variability, drought and heat stress on ET $[8,9]$.

Both SEB and SVAT models offer significant capabilities to predict wetland ET dynamics and moisture status [11]. These models principally work on constraining the water and energy balance to simulate the land surface fluxes, root zone soil water states, and temperature signals either in prognostic mode (SVAT) or in diagnostic (SEBS) manner. However, the accuracy of surface fluxes and ET simulated by SEB and SVAT models [12-17] are very sensitive to the parameterizations of the aerodynamic and surface (canopy-substrate complex) conductances $\left(\mathrm{g}_{\mathrm{A}}\right.$ and $\mathrm{g}_{\mathrm{S}}$ ) for heat and water transfer. Previous studies showed $\pm 25 \%$ error in simulated SEB fluxes due to the use of different $g_{A}$ and $g_{S}$ parameterizations [18]. Some of the major bottlenecks in retrieving $g_{A}$ and $g_{S}$ for simulating ET through SEB models are, (a) the lack of a benchmark parameterization to estimate both the conductances across a broad range of hydrometeorological and vegetation cover conditions [19-22], (b) the use of empirical response functions to characterize the conductances at the canopy-scale that have uncertain transferability in space and time [23-25], and (c) the sensitivity of the empirical models of $g_{A}$ and $g_{S}$ to different calibration parameters $[20,25]$. An extended description of $g_{A}-g_{S}$ uncertainties are given in Section 3.

ET estimation through SEB modelling is primarily based on bottom-up scaling approach where thermal infrared temperature (or radiometric surface temperature, $\mathrm{T}_{\mathrm{S}}$ ) is combined with radiation, meteorological, and vegetation index or leaf area index to simulate the sensible and latent heat fluxes $(\mathrm{H}$ and $\lambda E)[12,13]$. In the SEB models, $\lambda E$ is derived either as a residual of the SEB or through partitioning of the net available energy $(\phi)$ (i.e., net radiation, $R_{N}$-soil heat flux, $G$ ) [14-16]. One-source [19] and two-source $[17,26]$ SEB models can be differentiated, which either simulate lumped $\lambda E$ from the canopy-substrate complex (one-source) or $\lambda \mathrm{E}$ from canopy and substrate individually (two-source). Contrarily, SVAT models also simulate $\lambda \mathrm{E}$ but without the need of any a priori Ts information, instead the SVAT models simultaneously simulate $\lambda \mathrm{E}, \mathrm{H}$, and Ts through SEB subroutines. While SEB and SVAT models have been extensively used for understanding the hydrological and environmental impact on ET in various parts of the world [27-32], their performance has not been rigorously compared in the wetlands, particularly in the European wetland such as in the Upper Biebrza National Park (UBNP). 
Wetlands cover between $4 \%$ and $6 \%$ of the Earth's land surface [11,33] and Europe's wetlands occupy large areas in the northern part of the continent [34]. Wetlands are considered as the 'water-unlimited' extreme of the natural ecosystems, with substantial contribution in the global water cycles $[35,36]$. Wetlands provide a wide range of services such as nutrients recycling, storing and purifying water, augment and maintain stream flow, recharge groundwater [35], and provide habitats for a variety of living organisms [37]. The degradation of wetlands due to drought, heat stress, land drainage, river embankment and groundwater abstraction, and their restoration are major concerns to many government and non-governmental organizations [38,39]. The quantity and quality of the wetland water supply are vulnerable to hydrometeorological extremes [5,40,41], and climate change can substantially impact the wetland hydrological regimes due to the induced affects in the evaporative depletion [42].

Studies in the UBNP wetland have so far focused on developing groundwater model for hydrological analysis of the Biebrza Basin [43], linking conservation and restoration of deteriorated wetland with ecohydrological functioning [44], observational understanding of hydrography and surface water regime $[45,46]$, hydrodynamic modelling in the riverbed $[47,48]$, groundwater recharge [49], and understanding groundwater versus surface water interactions [50,51]. Because wetlands have saturated soils and high-water tables, ET is typically considered to be near potential and it is characterised through simple radiation-based models without explicit consideration of the conductances [52-54]. However, the large variability of ET in UBNP wetland precludes any generalization for particular plant communities or climatic regimes due to very challenging environments and heterogeneity in surface cover (e.g., percentage of bare soil, water and vegetation), hydrology and topography [7]. Differences in the relative cover of transpiring and non-transpiring vegetation as well as surface litters may have different surface and aerodynamic conductances with significant effects on ET rates [55]. By using two SEB and one SVAT models, the present study makes a critical assessment on the effects of the aerodynamic and surface conductance parameterizations for estimating ET in one the most ecologically significant North-East European wetland (i.e., UBNP) and addresses the following science questions and objectives.

1. What is the performance of the three structurally different SEB/SVAT models in the UBNP wetland when simulated with high temporal frequency measurements?

2. What are the effects of aerodynamic and surface conductances parameterizations and associated state variables in determining the model errors with respect to ET?

3. To what extent the ET modelling errors and conductance parameterizations are impacted by a range of environmental and ecohydrological conditions?

A description of methods including models, study sites, dataset, and data processing is given in Section 2, followed by the results in Section 3. An extended discussion of the results and potential of the SEB and SVAT models for evapotranspiration monitoring in the wetlands is elaborated in Sections 4 and 5, respectively. Symbols used for variables in this study are listed in the in Table S1 (Supplementary Materials).

\section{Materials and Methods}

\subsection{Model Description}

In this study, we used two structurally different SEB models and one SVAT model. The two SEB models are the Surface Energy Balance System (SEBS) [19] and Surface Temperature Initiated Closure (STIC) (version STIC1.2) [56,57], and the SVAT model is the Soil-Canopy-Observation of Photosynthesis and the Energy balance (SCOPE) (version SCOPE1.7) [58]. Among the three models, two are based on bottom-up scaling approach to resolve the surface energy balance components (SEBS and SCOPE1.7) and the other model applies top-down approach (STIC1.2) to estimate the SEB components. The fundamental difference of the three models and their input requirements are detailed 
in Table 1 and a detailed description of the governing equations are given in Supplementary Materials. A list of symbols and units are presented in Supplementary Materials Table S1. SCOPE1.7 being a SVAT model, tuning of certain input variables was necessary in order to reflect the seasonal variation of canopy biophysical and biochemical attributes. We implemented the Radiative Transfer Model optical (RTMo) model that is incorporated into the SCOPE model framework. The RTMo is composed of an extended versions of the SAIL [59] model and PROSPECT45 [60] model, now referred to as Fluspect. First, an ensemble of the canopy spectra was simulated which was followed by inversion of the RTMo to obtain the best match between the simulated and measured (Landsat 8) spectral reflectance through an iterative optimization approach [61]. An example of selected simulation and corresponding solutions is shown in Figure 1. A detailed overview of the SCOPE1.7 input parameters and variables used in the current study are found in the Table S2 of Supplementary Materials.

In the SEBS model, estimation of $z_{0 M}$ is critical. In this study we used NDVI (Normalized Difference Vegetation Index) to compute $\mathrm{z}_{0 \mathrm{M}}$ [62]. Using five (March, April, June, July, and August) Landsat-8 Near Infra-red (NIR) and Red reflectance spectral bands, we computed NDVI as NDVI = $(\mathrm{NIR}-\mathrm{Red}) /(\mathrm{NIR}+\mathrm{Red})$. We proceeded to interpolate the NDVI into 8-day composites and assigned each day to the nearest distance based on the observed trend.
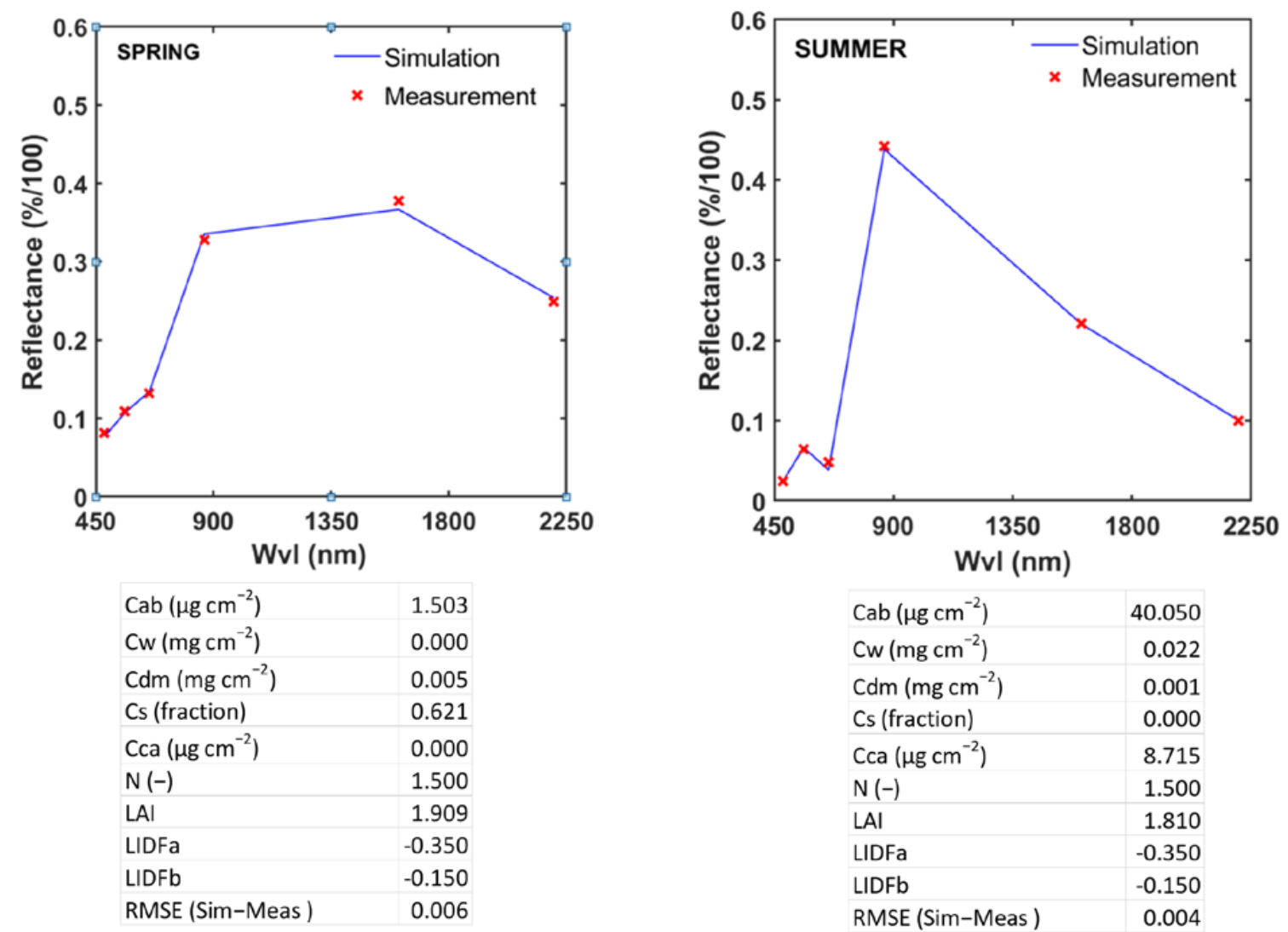

Figure 1. An example of simulated Landsat- 8 reflectance within a $3 \times 3$-pixel window around the Eddy covariance (EC) tower location acquired in Spring and Summer of 2015 by forward modelling and corresponding retrievals of the leaf and canopy properties obtained through model inversion using iterative optimization approach.

\subsection{Uncertainties in $g_{A}$ and $g_{S}$ Parameterizations in SEB and SVAT}

Surface energy balance simulation models use $\mathrm{T}_{\mathrm{S}}$ to constrain the energy-water fluxes $[16,28,63]$. The central aspect of contemporary SEB simulation is based on estimating $\mathrm{g}_{\mathrm{A}}$ and sensible heat flux $(\mathrm{H})$, while solving $\lambda \mathrm{E}$ as a residual SEB component. Estimation of $\mathrm{g}_{\mathrm{A}}$ relies on the Monin-Obukhov Similarity Theory (MOST) or Richardson Number (Ri) criteria, and $\mathrm{g}_{\mathrm{A}}$ estimates are subjected 
to uncertainties due to (a) empirical approximation of the displacement height $\left(\mathrm{d}_{0}\right)$ either as a simple function of vegetation height or leaf area index [64,65], (b) uncertainties in estimating the roughness length of momentum transfer $\left(\mathrm{z}_{0 \mathrm{M}}\right)$ and associated surface geometry [66], (c) challenges in accommodating the aerodynamic versus surface temperature inequalities, and (d) complexities in $\mathrm{kB}^{-1}$ parameterization $[67,68]$ to compensate for the differences in the scalar roughness lengths of heat $\left(\mathrm{z}_{0 \mathrm{H}}\right)$ and momentum $\left(\mathrm{z}_{0 \mathrm{M}}\right)$ transfer. The parameters $\mathrm{d}_{0}, \mathrm{z}_{0 \mathrm{M}}, \mathrm{z}_{0 \mathrm{H}}$, and $\mathrm{kB}^{-1}$ are the highly variable components in SEB models, and the commonly used empirical response functions of these components to characterize $g_{A}$ have an uncertain transferability in space and time $[69,70]$. An extended description of the impacts of ambiguous parameterization of $\mathrm{d}_{0}, \mathrm{z}_{0 \mathrm{M}}, \mathrm{kB}^{-1}$ on ET estimates is detailed by $[67,71,72]$.

SVAT models represent electrical resistance network analogy through mathematical representation of the detailed physical mechanisms that controls the energy and mass transfers in the soil/vegetation/atmosphere continuum [73]. Surface energy balance is an integral part of the SVAT models and are mainly used to simulate the coupled exchanges of energy-water-carbon to the ecosystem level. In addition to the aerodynamic conductance, SVAT models use different formulations of stomatal (or canopy-surface) conductance and plant hydraulics. However, there is no common consensus on which gS model matches best with the observed surface energy balance fluxes [74]. Therefore, there is a critical need to assess the impact of aerodynamic and canopy-surface conductance representation on the performance of SEB and SVAT models.

\subsection{Eddy Covariance Estimation of $g_{A}$ and $g_{S}$ for Model Evaluation}

Due to the lack of direct $g_{A}$ measurements, a rigorous evaluation of $g_{A}$ from the models is challenging. However, an indirect evaluation of $g_{A}$ retrievals from the three models was performed using the micrometeorological measurements from the EC towers. By using the measured friction velocity $\left(\mathrm{u}^{*}\right)$ and wind speed $(\mathrm{u})$ at the EC towers and using the equation of [75] we estimated $\mathrm{g}_{\mathrm{A}}$ as the sum of turbulent conductance and canopy (quasi-laminar) boundary-layer conductance as follows.

$$
\mathrm{g}_{\mathrm{A}}(\mathrm{EC} \text { tower })=\left[\left(\mathrm{u} / \mathrm{u}^{* 2}\right)+\left(2 / \mathrm{ku}^{* 2}\right)(\mathrm{Sc} / \mathrm{Pr})^{0.67}\right]^{-1}
$$

where k is von Karman's constant, 0.4; Sc is the Schmidt Number; Pr is the Prandtl Number and their ratio is generally considered to be unity. Here the conductances of momentum, sensible and latent heat fluxes are assumed to be identical [57].

Similar to $\mathrm{g}_{\mathrm{A}}$, a direct evaluation modeled $\mathrm{g}_{\mathrm{S}}$ could not be performed, as independent ecosystem-scale $g_{S}$ observations are not possible with current measurement techniques. Assuming $\mathrm{u}^{*}$-based $\mathrm{g}_{\mathrm{A}}$ as the baseline aerodynamic conductance, we estimated $\mathrm{g}_{\mathrm{S}}$ by inverting the Penman-Monteith equation [76] to evaluate the modeled $g_{S}$. Here $\mathrm{u}^{*}$-based $\mathrm{g}_{\mathrm{A}}$ was used in conjunction with the net available energy, $\lambda \mathrm{E}$, air temperature, and humidity measurements from the EC towers [57] as follows.

$$
\mathrm{g}_{\mathrm{S}}(\mathrm{EC} \text { Tower })=\frac{\gamma \mathrm{g}_{\mathrm{A}} \lambda \mathrm{E}}{\mathrm{s}\left(\mathrm{R}_{\mathrm{N}}-\mathrm{G}\right)-\rho \mathrm{c}_{\mathrm{P}} \mathrm{g}_{\mathrm{A}} \mathrm{D}_{\mathrm{A}}-\lambda \mathrm{E}(\mathrm{s}+\gamma)}
$$

Here $\gamma$ is the psychrometric constant, $\mathrm{s}$ is the slope of saturation vapor pressure versus air temperature relationship, $R_{N}-G$ is the net available energy, $\rho$ and $c_{p}$ are the density and specific heat of air, respectively.

Among the three models, SEBS does not estimate $g_{S}$. However, from the estimated $g_{A}$ and $\lambda E$ (of SEBS), an inverse estimation of SEBS-based $g_{S}$ was also performed for comparing with the EC $g_{S}$ estimates in the framework of Penman-Monteith equation. 
Table 1. A summary overview of features, inputs-outputs and conductance parameterization characteristics of the two SEB and one SVAT model.

\begin{tabular}{|c|c|c|c|c|c|}
\hline SEB Model & Feature & Inputs & & Outputs & Surface Parameterization \\
\hline & & Meteo & LeaflCanopy & & \\
\hline $\begin{array}{c}\text { STIC } 1.2 \\
{[57,77]}\end{array}$ & $\begin{array}{c}\text { Single source } \\
\text { Derivative of PM-WS } \\
\text { Integrates } \mathrm{T}_{\mathrm{s}} \text { into PM } \\
\lambda \mathrm{E} \text { directly estimated from SEB } \\
\end{array}$ & $\begin{array}{l}\mathrm{T}_{\mathrm{A}}, \mathrm{T}_{\mathrm{D}}, \mathrm{RS}_{\text {in }}, \mathrm{RS}_{\text {out }} \\
\mathrm{G}, \phi, \mathrm{T}_{\mathrm{S}}\end{array}$ & & $\mathrm{g}_{\mathrm{A}}, \mathrm{g}_{\mathrm{S}}, \mathrm{T}_{0}, \lambda_{\mathrm{r}}, \mathrm{M}, \mathrm{H}, \lambda \mathrm{E}$ & $\begin{array}{c}\text { Analytically computes } g_{A} \text { and } g_{S} \\
\text { Calibration free estimates of conductances }\end{array}$ \\
\hline $\begin{array}{l}\text { SEBS } \\
{[19]}\end{array}$ & $\begin{array}{c}\text { Single source } \\
\text { Uses MOST to solve for } \mathrm{H} \\
\text { Scales } \mathrm{H} \text { between hypothetical } \\
\text { wet and dry limit } \\
\text { Estimates } \lambda \mathrm{E} \text { as a residual component of SEB }\end{array}$ & $\begin{array}{c}\mathrm{T}_{\mathrm{A}}, \mathrm{T}_{\mathrm{D}}, \mathrm{RS}_{\text {in }}, \mathrm{RS}_{\text {out }}, \\
\mathrm{G}, \phi, \mathrm{T}_{\mathrm{S}} \\
\mathrm{p}_{\mathrm{a},} \mathrm{u}\end{array}$ & $\begin{array}{l}\mathrm{h}, \mathrm{fc}, \mathrm{z}_{\mathrm{OH}}, \mathrm{z}_{\mathrm{OM}}, \mathrm{d}_{0} \\
\quad \text { NDVI, LAI }\end{array}$ & $\mathrm{g}_{\mathrm{A}}, \lambda_{\mathrm{r}}, \mathrm{kB}^{-1}, \mathrm{H}, \lambda \mathrm{E}$ & $\begin{array}{l}\text { Assumes } T_{\mathrm{S}} \text { and } \mathrm{T}_{0} \text { are equal } \\
\text { Assumes kB-1 adjusts the inequality between the } \\
\text { roughness lengths of momentum and heat transfers }\end{array}$ \\
\hline $\begin{array}{l}\text { SCOPE } 1.7 \\
{[58]}\end{array}$ & $\begin{array}{c}\text { Multi source } \\
\text { Applies SVAT principle } \\
\text { Flux transfer based on K-theory } \\
{[23]}\end{array}$ & $\begin{array}{c}\mathrm{T}_{\mathrm{A}}, \mathrm{e}_{\mathrm{A}}, \mathrm{RS}_{\mathrm{in}}, \mathrm{RL}_{\mathrm{in}} \\
\mathrm{p}_{\mathrm{a}}, \mathrm{u}\end{array}$ & $\begin{array}{c}\text { PROSPECT [78] inputs } \\
\text { Vcmo, m, } \\
\mathrm{h}_{\mathrm{c}} \text {, LAI, LDFa, LIDFb, LW } \\
\text { Soil thermal properties, SMC } \\
\mathrm{z}_{0 \mathrm{H}}, \mathrm{z}_{0 \mathrm{M}}, \mathrm{d}_{0} \\
\mathrm{rbs}, \mathrm{rss}, \mathrm{rwc} \\
\text { VZA, RAA, SZA }\end{array}$ & $\begin{array}{c}\mathrm{g}_{\mathrm{A}}, \mathrm{g}_{\mathrm{S} \text { (leaf) }}, \mathrm{H}, \mathrm{G}, \lambda \mathrm{E} \\
\mathrm{R}_{\mathrm{N}}, \mathrm{RS}_{\text {out }}, \mathrm{u}^{*}\end{array}$ & $\begin{array}{l}\text { Computes } \mathrm{g}_{\mathrm{A}} \text { at (inertial, roughness and canopy) } \\
\text { Computes } \mathrm{g}_{\mathrm{S}} \text { at leaf level }\end{array}$ \\
\hline
\end{tabular}




\subsection{Study Site: Ecological and Hydrological Significance of UBNP Wetland}

The Biebrza is the largest National Park in Poland, and it covers an area of over 59,000 hectares [45]. The area experiences sub-continental/sub-boreal climate with an annual average temperature of 6.8 ${ }^{\circ} \mathrm{C}$, precipitation ranging between 550 to $700 \mathrm{~mm}$ year ${ }^{-1}$ and evapotranspiration between 460 and 480 $\mathrm{mm}$ year $^{-1}$ [40]. It is located $230 \mathrm{~km}$ North East of Warsaw being serviced by the Biebrza River which is a right sided tributary of the Narew River. The UBNP wetland is situated within the upper Biebrza river catchment $\left(22^{\circ} 30^{\prime}-23^{\circ} 60^{\prime} \mathrm{E}, 53^{\circ} 30^{\prime}-53^{\circ} 75^{\prime} \mathrm{N}\right)$. While the lower part of Biebrza experiences a sequence of flood events often after snowmelt in early spring, the upper part of the Biebrza river basin rarely experiences flooding. Most part of the surface runoff takes place within the drainage network [46]. During the dry periods, the wetland is groundwater fed. Most part of the surface runoff in UBNP takes place within the drainage network [46].

Upper Biebrza is the region of large variety of wetland habitats and typically driven by local hydrology [44,79]. The substrate is mainly composed of natural peat supporting highly productive tall sedge, reeds and grass [44]. The ecosystem offers habitat and breeding ground for numerous species of which up to 21 species have been listed as threatened in Europe including but not limited to snipe, aquatic warbler, elk, otters and European beaver [44]. Biebrza valley can be considered as a reference for other similar ecosystems in Western and Central Europe since $96 \%$ of the present plant species also belong to the Dutch flora $[79,80]$. Currently, the UBNP wetland is listed under the RAMSAR convention as one of the most important wetlands worldwide designated under protected river valley [45].

\subsection{Datasets}

In this analysis, we have used eddy-covariance (EC) observations from the Rogozynk EC tower site for the two consecutive years of 2015 and 2016 from spring (March) to mid-summer (July) period. These periods were selected because 2015 and 2016 experienced contrasting precipitation amounts according to the meteorological bureau report and also due to the data availability. Whereas summer of 2015 was actually characterized by very low precipitation (amounting to $50 \%$ of the seasonal average computed over the period 1971-2000); the precipitation amounts in spring/summer 2016 were close to the normal trend [7] (Figure 2).

The EC data were available at half-hourly temporal resolution from 5th March to 22nd July for both the years. Data used for this analysis included time series of surface energy balance fluxes $\left(R_{N}, \lambda E, H\right.$, and $\left.G\right)$, shortwave and longwave radiation components $\left(R S_{\text {in }}, R S_{\text {out }}, R L_{\text {in }}, R L_{\text {out }}\right)$, and hydrometeorological variables (e.g., $\mathrm{T}_{\mathrm{A}}, \mathrm{R}_{\mathrm{H}}, \mathrm{u}, \mathrm{u}^{*}, \theta$, and $\mathrm{P}$ ). Assuming nighttime ET to be negligible in the wetland [10,81], daily ET (in $\mathrm{mm}$ ) was computed by integrating half-hourly $\lambda \mathrm{E}$ from sunrise to sunset (corresponds to positive magnitude of $\mathrm{RS}_{\text {in }}$ ). However, it is also important to mention that wetlands in the arid and semi-arid regions could show substantial amount of ET during night and careful daily ET averaging is needed in such cases [82]. Weekly ET (in mm) was computed by summing daily ET. We did not perform any gap filling, which implies that missing observed or estimated sub-daily or daily ET values were not included in the computation. The energy balance closure of the EC site was $92 \%$ and the surface energy balance was closed using the Bowen ratio energy balance method as described in $[27,56,83]$.

Surface emissivity $\left(\varepsilon_{\mathrm{s}}\right)$ was assumed to be 0.98 and Ts was computed by inverting the longwave radiation measurements as follows.

$$
\mathrm{T}_{\mathrm{S}}=\left[\frac{\mathrm{RL}_{\text {out }}-\left(1-\varepsilon_{\mathrm{S}}\right) R L_{\text {in }}}{\sigma \varepsilon_{\mathrm{S}}}\right]^{0.25}-273
$$

Albedo computation was based on the ratio between the downwelling and upwelling shortwave radiation $\left(\alpha_{0}=\frac{R S_{\text {out }}}{R S_{\text {in }}}\right)$. 


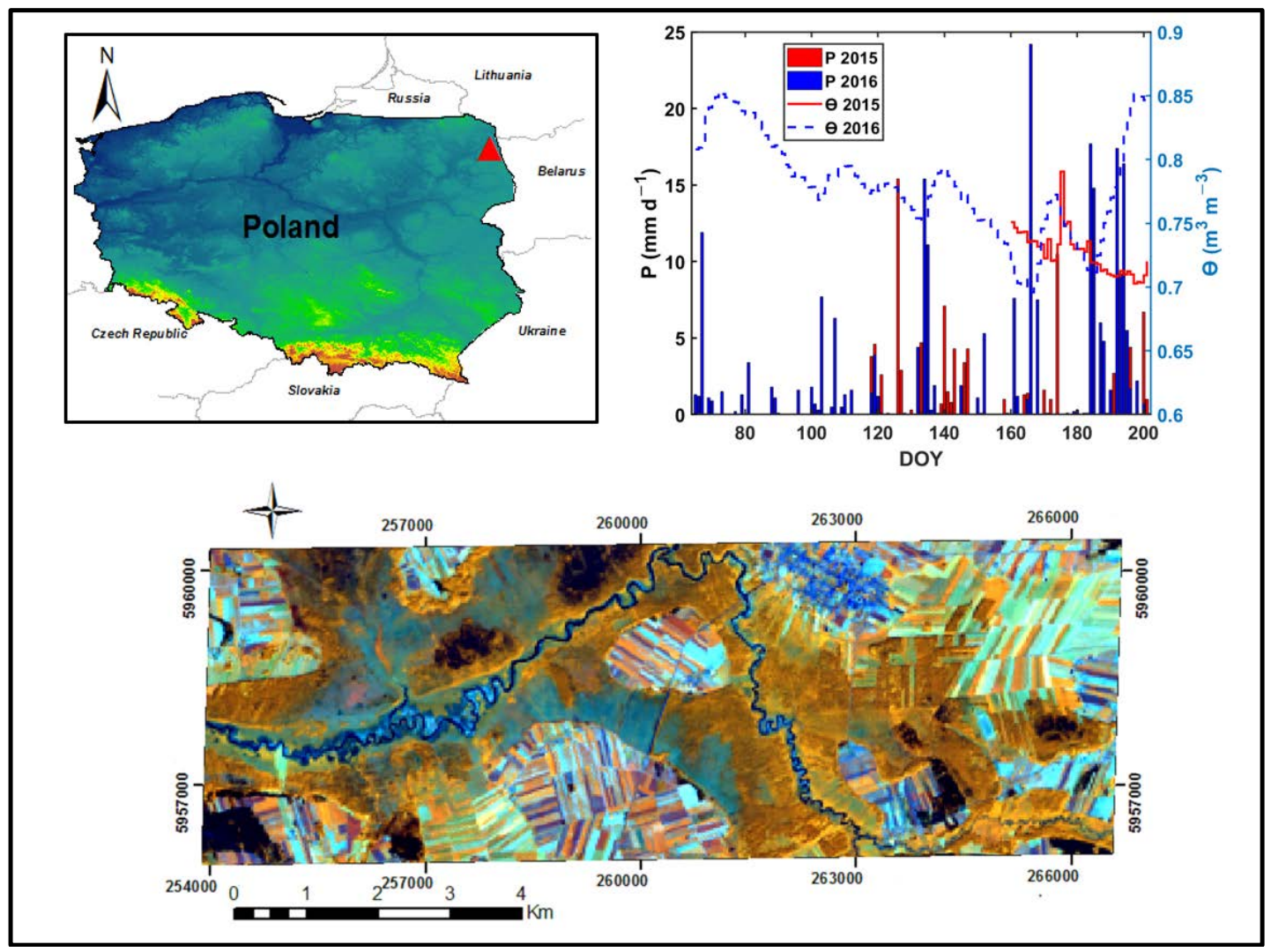

Figure 2. Study area in the Upper Biebrza National Park (UBNP) wetland based on a Landsat-8 scene. The distribution of precipitation (P) and soil moisture $(\theta)$ for the year 2015 and 2016 is also shown in the primary $y$-axis $(\mathrm{P})$ and secondary $\mathrm{y}$-axis $(\theta)$, respectively.

\subsection{Model Evaluation and Comparison}

ET estimates from the respective models were compared with measured ET. The relative performance of each model was evaluated using the following statistical indices namely the coefficient of determination $\left(\mathrm{R}^{2}\right)$, the root mean square error (RMSE), the mean absolute percentage deviation (MAPD), the regression slope, and the regression intercept, respectively.

$$
\begin{aligned}
\mathrm{R}^{2} & =\frac{\sum_{i=1}^{n}\left(p_{i}-o_{i}\right)^{2}}{\sum_{i=1}^{n}\left(o_{i}-\overline{o_{i}}\right)^{2}} \\
\mathrm{RMSE} & =\sqrt{\frac{\sum_{i=1}^{n}\left(p_{i}-o_{i}\right)^{2}}{n}} \\
\mathrm{MAPD} & =\frac{1}{n} \sum_{i=1}^{n} \frac{\left|p_{i}-o_{i}\right|}{o_{i}} \times 100
\end{aligned}
$$

where, $n$ is the number of data points; $o_{i}$ and $p_{i}$ are observed and estimated $\lambda \mathrm{E}$ and ET; $\overline{o_{i}}$ is the mean of observations.

\subsection{Relationship between ET Modeling Errors, Conductances, and Ecohydrological Factors}

To understand the effects of the aerodynamic and canopy-surface conductances and associated variables on $\lambda \mathrm{E}$ simulation, we analyzed the relationship between the residual $\lambda \mathrm{E}$ errors of individual models with the simulated conductances and associated variables. The degree of relationship was assessed through the correlation $(r)$ values and the significance of correlation was tested by the $p$-value. The $p$-value signifies the probability that we would have found the current results in residual error 
analysis if the correlation coefficient is zero (i.e., null hypothesis). If the $p$-value is less than $5 \%$ (i.e., $p$-value $<0.05$ ), the correlation coefficient is considered as statistically significant.

To examine the influence of ecohydrological conditions on ET prediction errors and biophysical conductances, we further investigated the patterns of mean bias (MB) in weekly ET in comparison to the weekly soil moisture $(\theta)$ and climatic aridity or dryness (i.e., annual $\mathrm{E}_{\mathrm{P}} / \mathrm{P}$ ) [84] which are considered to represent the general ecohydrological characteristics of ecosystems. UBNP wetland ecosystem generally has high magnitude of soil moisture and low $\mathrm{E}_{\mathrm{P}} / \mathrm{P}$ (low evaporative demand and high precipitation). Therefore, an independent assessment of the effects of $E_{\mathrm{P}} / \mathrm{P}$ and $\theta$ on the predictive capacity of the SEB and SVAT models is crucial. Results of the correlation analysis between $\mathrm{MB}$ in weekly ET with weekly $\theta$ and weekly $\mathrm{E}_{\mathrm{P}} / \mathrm{P}$ are presented in Section 3.3, and discussions on the effects of $\theta$ and weekly $E_{\mathrm{P}} / \mathrm{P}$ on the biophysical conductance simulations are elaborated in Section 5.

\section{Results}

\subsection{Statistical Intercomparison of the Conductances and $\lambda E(E T)$ Estimates from SCOPE1.7, STIC1.2 and} SEBS Models

\subsubsection{Evaluation of $g_{A}$ and $g_{S}$ Estimates from Models}

An evaluation of ecosystem-scale $g_{A}$ is illustrated in Figure 3a combining data from both the years. While the estimated $g_{A}$ values ranged between $0-0.06 \mathrm{~m} \mathrm{~s}^{-1}$ for STIC1.2 and SEBS, it was $0-0.6 \mathrm{~m} \mathrm{~s}^{-1}$ for SCOPE1.7, with $R^{2}$ ranged between 0.13 to 0.80 between the tower-observed $g_{A}$ and modelled $g_{A}$. Statistical comparisons between the models revealed that although SCOPE1.7 had a good $\mathrm{R}^{2}$, but the magnitude of $\mathrm{g}_{\mathrm{A}}$ from SCOPE1.7 is ten times higher with respect to the tower observations. As seen in Figure $3 \mathrm{a}$, there appears to be a strong systematic bias in SCOPE1.7 $\mathrm{g}_{\mathrm{A}}$ which led to very high BIAS and MAPD. Overall, the mean bias and MAPD in modeled $g_{A}$ varied between $0.003-0.12 \mathrm{~m} \mathrm{~s}^{-1}$ and 81 to $93 \%$, respectively.

Canopy-scale evaluation of half-hourly $g_{S}$ is presented in Figure $3 b$ and the estimated values ranged between $0-0.06 \mathrm{~m} \mathrm{~s}^{-1}$ for STIC1.2, $0-0.2 \mathrm{~m} \mathrm{~s}^{-1}$ for SCOPE1.7, and 0-0.01 $\mathrm{m} \mathrm{s}^{-1}$ for SEBS. The magnitude of $R^{2}$ varied from $0.15-0.53$, with mean bias and MAPD of $-0.004-0.1 \mathrm{~m} \mathrm{~s}^{-1}$ and $73-86 \%$, respectively. Like $g_{A}$, a systematic overestimation of $g_{S}$ was also found in SCOPE1.7 which is consequently revealed in very high mean bias and MAPD.

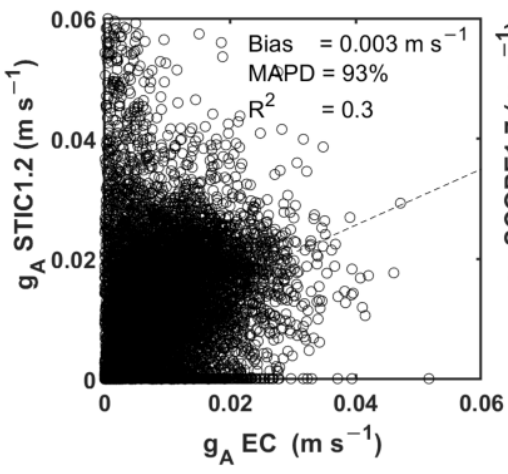

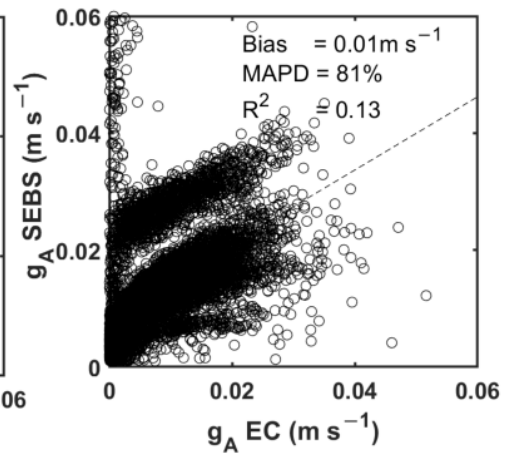

(a)

Figure 3. Cont. 

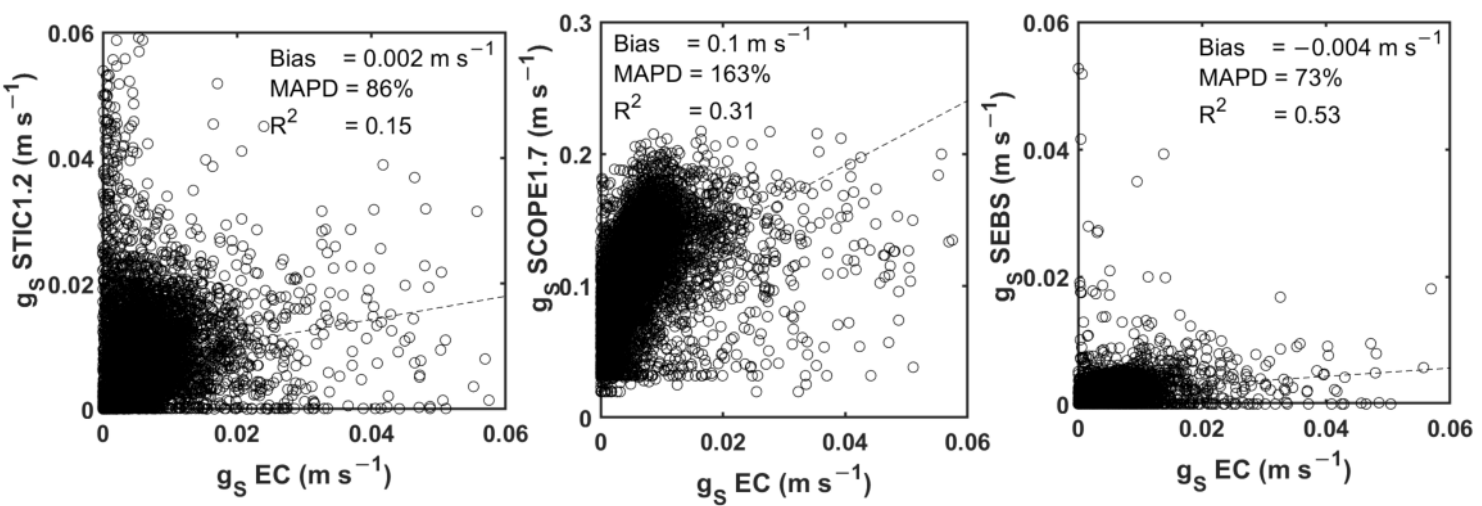

(b)

Figure 3. (a) Comparison between model derived $g_{A}$ estimates with an estimated aerodynamic conductance based on friction velocity $\left(\mathrm{u}^{*}\right)$ and wind speed $(\mathrm{u})$ according to [75], (b) Comparison between model derived $g_{S}$ estimates with respect to $g_{S}$ computed by inverting the penman-Monteith model where $g_{A}$ estimates from EC tower were used as aerodynamic input in conjunction with tower measurements of $\lambda \mathrm{E}$, radiation and meteorological variables.

\subsubsection{Evaluation of $\lambda \mathrm{E}$ (ET) Estimates from Models}

Given the structural differences between the three models in computing the SEB components, this section describes the performance of the models through evaluating the predictive capacity of half-hourly $\lambda \mathrm{E}$ for spring, summer, and entire growth period for the years 2015 and 2016. The statistical evaluation of daily ET (integration of half-hourly $\lambda \mathrm{E}$ for the daytime) is also presented afterwards.

Scatterplots of predicted versus observed $\lambda$ E revealed SCOPE1.7 and STIC1.2 to explain $80-91 \%$ $\left(R^{2}=0.80-0.91\right)$ and $91-92 \%\left(R^{2}=0.91-0.92\right)$ of the variations in observed $\lambda E$ for the entire growing season in both years (Figure 4a,b). Seasonal evaluation of the models revealed marginal differences between STIC1.2 and SCOPE1.7 performance in both years, although both models captured relatively low $\lambda E$ variations $\left(R^{2}=0.74\right.$ and 0.90$)$ in summer 2015 as compared to the summer 2016 (Figure $\left.4 c-f\right)$.

SEBS captured to a lesser extent the variations in observed $\lambda \mathrm{E}$ for both annually $\left(\mathrm{R}^{2}=0.67-0.80\right)$ and seasonally $\left(R^{2}=0.62-0.83\right)$ in both years (Figure 4$)$. Comparison of the statistical error metrics of the model performance (Table 2) revealed SEBS to produce the highest RMSE $\left(62-75 \mathrm{~W} \mathrm{~m}^{-2}\right)$ and MAPD (24-46\%) (for the entire growing season as well as summer and spring), followed by SCOPE1.7 (37-52 $\left.\mathrm{W} \mathrm{m}^{-2}, 22-32 \%\right)$ and STIC1.2 (29-31 $\left.\mathrm{W} \mathrm{m}^{-2}, 18-19 \%\right)$. As evident from the slope of the linear regressions and mean bias (Table 2), while SEBS and STIC1.2 underestimated $\lambda E$; SCOPE1.7 had overestimated $\lambda \mathrm{E}$ in both years, regardless of the season. 


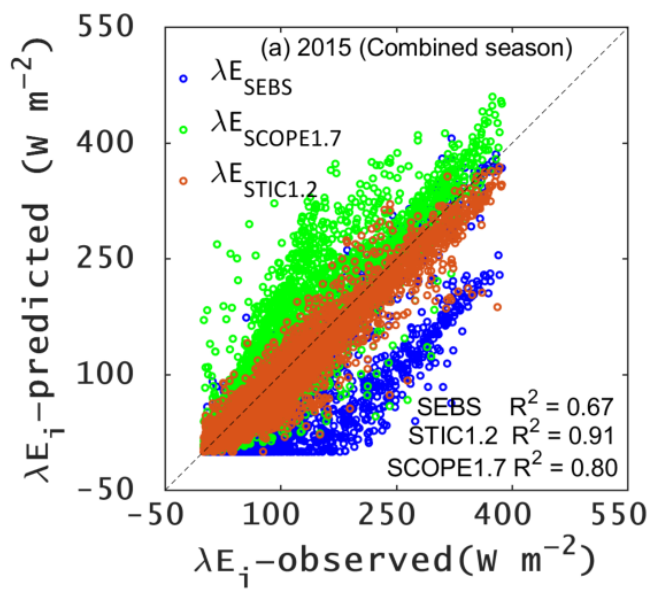

(a)

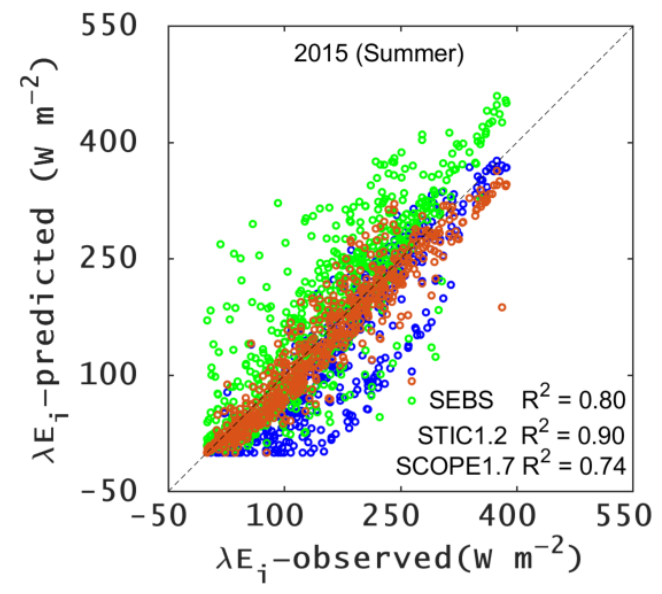

(c)

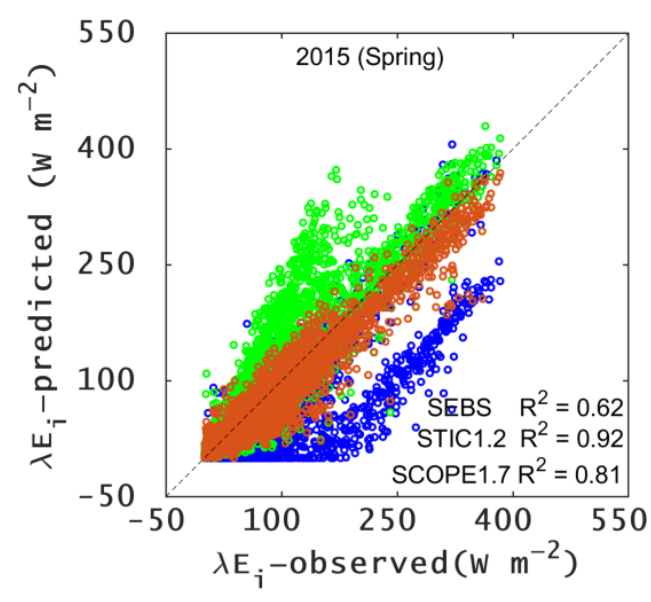

(e)

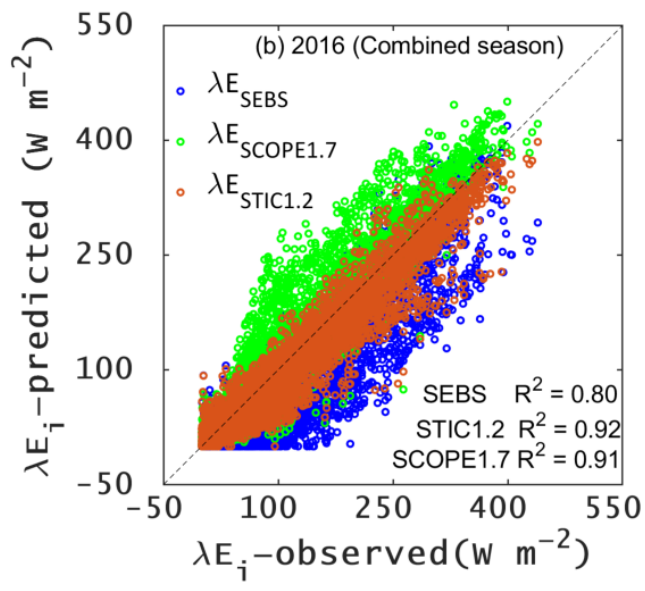

(b)

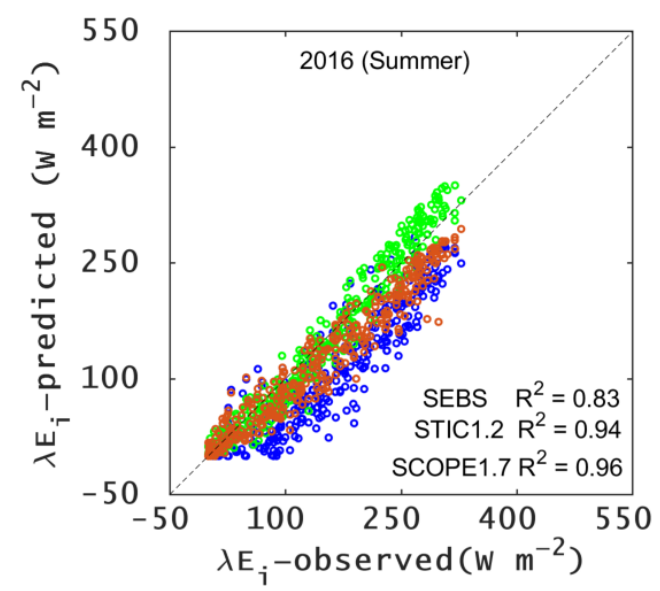

(d)

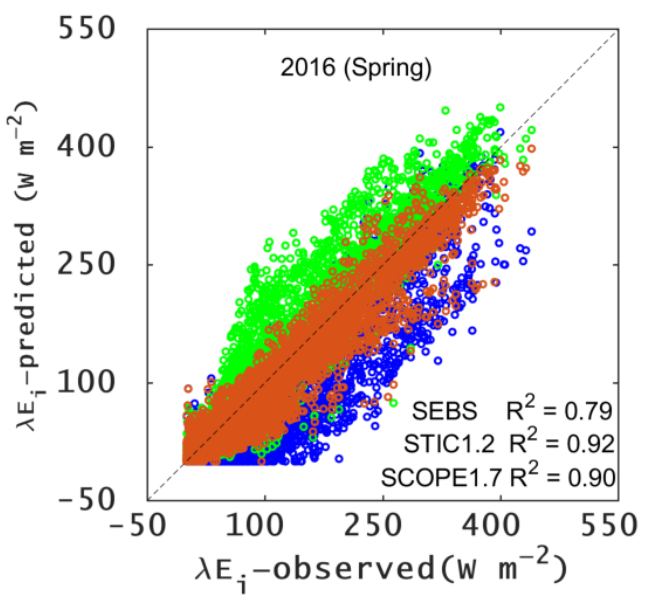

(f)

Figure 4. Evaluation of half-hourly latent heat flux $(\lambda \mathrm{E})$ from STIC1.2, SEBS, and SCOPE1.7 for entire growing season $(\mathbf{a}, \mathbf{b})$, for the spring $(\mathbf{c}, \mathbf{d})$ and for the summer $(\mathbf{e}, \mathbf{f})$ months during the two consecutive years of 2015 and 2016. 
Table 2. Error Statistics of half-hourly $\lambda$ E from the two SEB and one SVAT models in the UBNP wetland (Site: Rogozynk) in two contrasting rainfall years.

\begin{tabular}{|c|c|c|c|c|c|c|c|c|c|c|c|c|c|c|c|c|c|c|c|}
\hline \multirow[b]{2}{*}{ Year } & \multirow[b]{2}{*}{ Model } & \multicolumn{6}{|c|}{ Full Season } & \multicolumn{6}{|c|}{ Spring } & \multicolumn{6}{|c|}{ Summer } \\
\hline & & $\mathbf{R}^{2}$ & Slope & Intercept & $\begin{array}{l}\text { RMSE, } \\
\mathrm{W} \mathrm{m}^{-2}\end{array}$ & $\begin{array}{c}\text { MAPD, } \\
\%\end{array}$ & $\begin{array}{c}\mathrm{MB} \\
\mathrm{W} \mathrm{m}^{-2}\end{array}$ & $\mathbf{R}^{2}$ & Slope & Intercept & $\begin{array}{l}\text { RMSE, } \\
\mathrm{W} \mathrm{m}^{-2}\end{array}$ & $\begin{array}{c}\text { MAPD, } \\
\%\end{array}$ & $\begin{array}{c}\mathrm{MB}, \\
\mathrm{W} \mathrm{m}^{-2}\end{array}$ & $\mathbf{R}^{2}$ & Slope & Intercept & $\begin{array}{l}\text { RMSE, } \\
\mathrm{W} \mathrm{m}^{-2}\end{array}$ & $\begin{array}{c}\text { MAPD, } \\
\%\end{array}$ & $\begin{array}{c}\mathrm{MB}, \\
\mathrm{W} \mathrm{m}^{-2}\end{array}$ \\
\hline \multirow{3}{*}{2015} & SCOPE1.7 & 0.8 & 1.06 & 16 & 52 & 32 & 23 & 0.81 & 1.05 & 16 & 49 & 32 & 22 & 0.74 & 1.07 & 15 & 64 & 32 & 25 \\
\hline & SEBS & 0.67 & 0.84 & -3 & 75 & 40 & -51 & 0.62 & 0.73 & -21 & 80 & 46 & -57 & 0.8 & 1.06 & -43 & 55 & 24 & -33 \\
\hline & STIC1.2 & 0.91 & 0.91 & -2 & 29 & 18 & -13 & 0.92 & 0.89 & -1 & 28 & 19 & -13 & 0.9 & 0.96 & -3 & 30 & 15 & -10 \\
\hline \multirow{3}{*}{2016} & SCOPE1.7 & 0.91 & 1.08 & 5 & 37 & 22 & 14 & 0.9 & 1.09 & 6 & 38 & 23 & 15 & 0.96 & 1.08 & -11 & 21 & 12 & -0 \\
\hline & SEBS & 0.8 & 0.91 & -30 & 62 & 33 & -43 & 0.79 & 0.91 & -30 & 62 & 33 & -42 & 0.83 & 0.87 & -28 & 61 & 32 & -50 \\
\hline & STIC1.2 & 0.92 & 0.88 & 1 & 31 & 19 & -13 & 0.92 & 0.89 & 1 & 30 & 19 & -12 & 0.94 & 0.84 & 0 & 34 & 19 & -23 \\
\hline
\end{tabular}


Time-series progression of daily ET ( $\mathrm{mm} \mathrm{day}^{-1}$ ) (Figure 5) showed large variability in day-to-day ET during the summer months (June-July) $(1-7 \mathrm{~mm})$ which is reasonably captured by all the models. Maximum ET was found to occur during June-July $(7 \mathrm{~mm})$ and minimum ET was observed during spring (1-3 mm). Among the three models, SEBS revealed consistent underestimation which was more pronounced during the spring. However, SEBS captured the daily ET trend slightly better than the other two models during the dry-down phase of late summer in the year 2016, whereas SCOPE1.7 (STIC1.2) revealed substantial (little) overestimation tendency during this period.

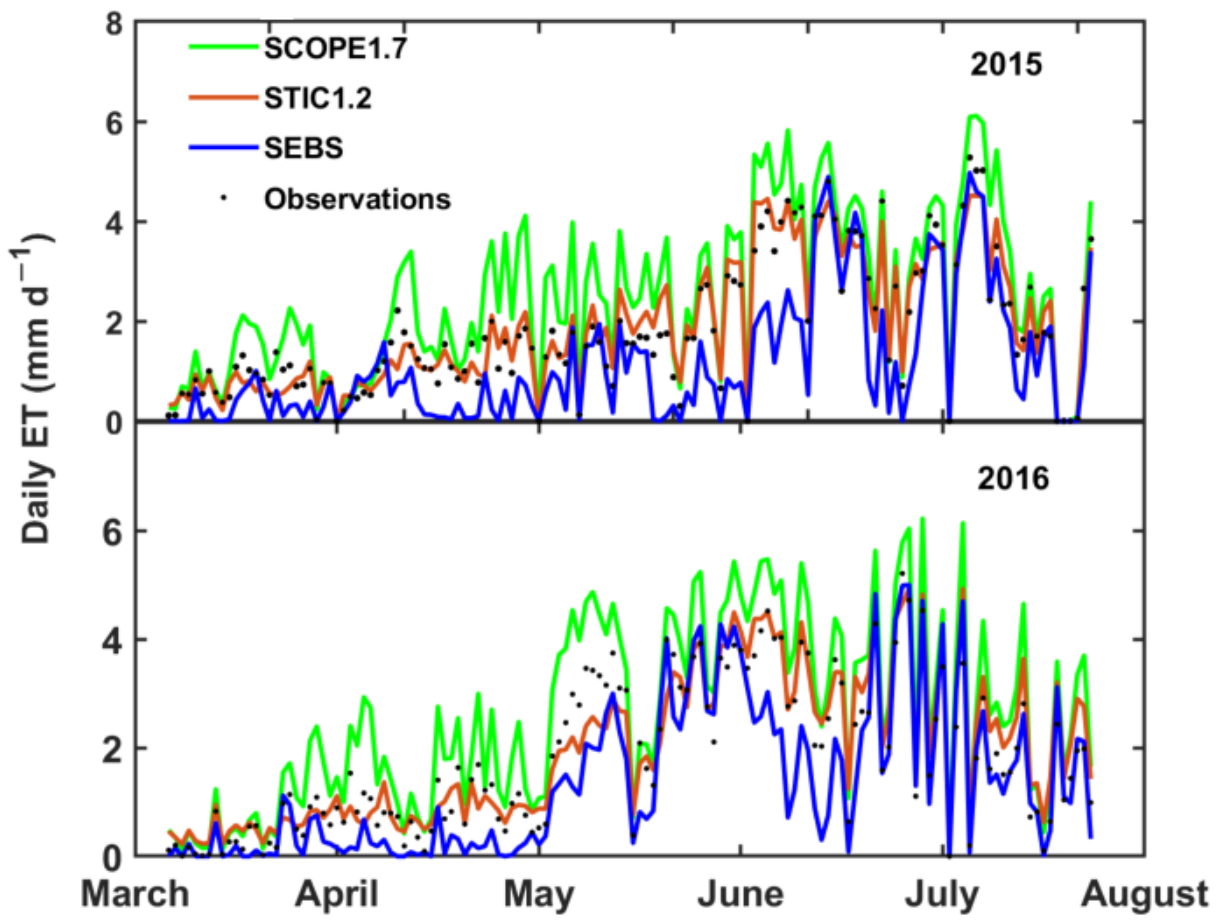

\section{Months}

Figure 5. Time series of simulated and observed daily ET from SCOPE1.7, SEBS and STIC1.2 for years 2015 and 2016.

An analysis of daily error statistics revealed $\mathrm{R}^{2}$ and RMSE of SCOPE1.7 (and STIC1.2) to be 0.87-0.95 (0.89-0.92) and 0.89-0.92 $\mathrm{mm} \mathrm{day}^{-1}\left(0.37-0.46 \mathrm{~mm} \mathrm{day}^{-1}\right)$ (Table 3), with a consistent overestimation (underestimation) of daily ET from SCOPE1.7 (STIC1.2). While the MAPD of STIC1.2 varied between $16-21 \%$, it was 38-44\% for SCOPE1.7, and both models showed relatively high MAPD in 2016. For SEBS, the RMSE and MAPD in daily ET was $0.74-0.95 \mathrm{~mm}$ and $33-40 \%$, respectively (Table 3).

Table 3. Error Statistics of daily ET from the three models in the UBNP wetland (Rogozynk) in the two contrasting rainfall years of 2015 and 2016.

\begin{tabular}{cccccc}
\hline Year & Model & $\mathbf{R}^{\mathbf{2}}$ & RMSE $\left(\mathbf{m m}\right.$ day $\left.^{-\mathbf{1}}\right)$ & MAPD (\%) & MB (mm day \\
\hline \multirow{2}{*}{2015} & SCOPE1.7 & 0.87 & 0.89 & 38 & 0.67 \\
& SEBS & 0.75 & 0.95 & 40 & -0.68 \\
& STIC1.2 & 0.92 & 0.37 & 16 & -0.05 \\
\hline \multirow{2}{*}{2016} & SCOPE1.7 & 0.95 & 0.92 & 44 & 0.79 \\
& SEBS & 0.80 & 0.74 & 33 & -0.46 \\
& STIC1.2 & 0.89 & 0.46 & 21 & -0.14 \\
\hline
\end{tabular}




\subsection{Effects of Biophysical Conductance Parameterization on Residual Error of the Models}

The effects of biophysical parameterization in the propagation of model errors are presented in the box and violin plots (Figure 6$)$ which showed the residual $\lambda E$ error $\left(\Delta_{\lambda E}\right)(=$ predicted - observed) for different classes of simulated conductances, $\mathrm{T}_{0}$ and $\mathrm{T}_{\mathrm{c}}$ for STIC1.2 and SCOPE1.7. Since SEBS does not simulate the surface conductance, the model errors for SEBS are assessed by relating $\Delta_{\lambda \mathrm{E}}$ with the aerodynamic conductance, $\mathrm{kB}^{-1}$ and $\mathrm{z}_{0 \mathrm{M}}$.

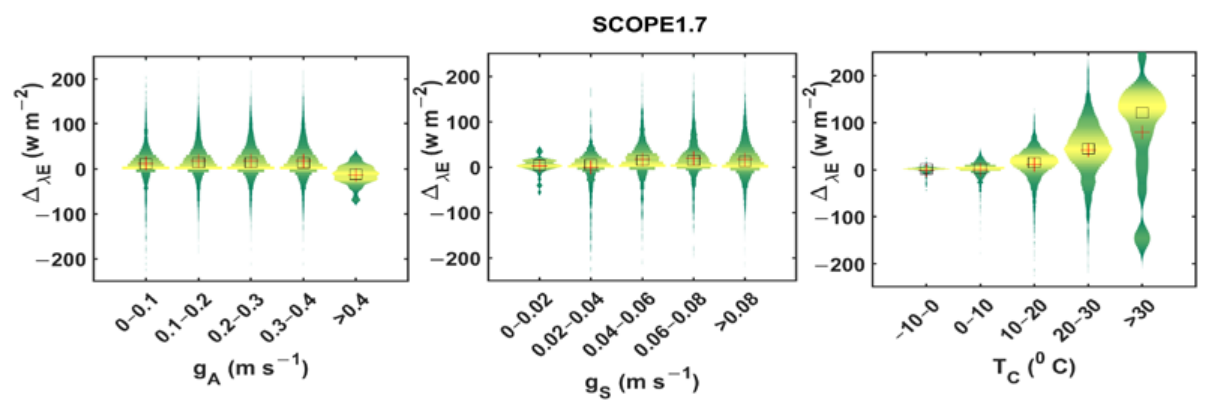

(a)

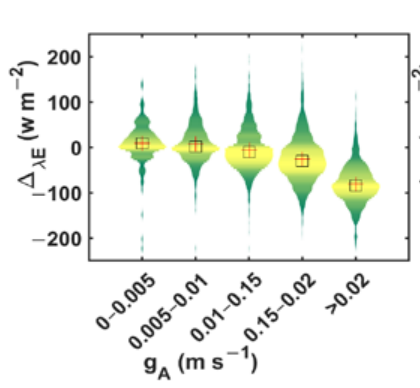

SEBS

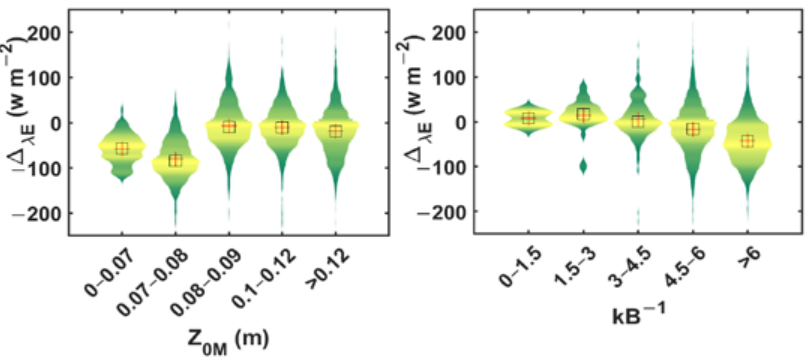

(b)
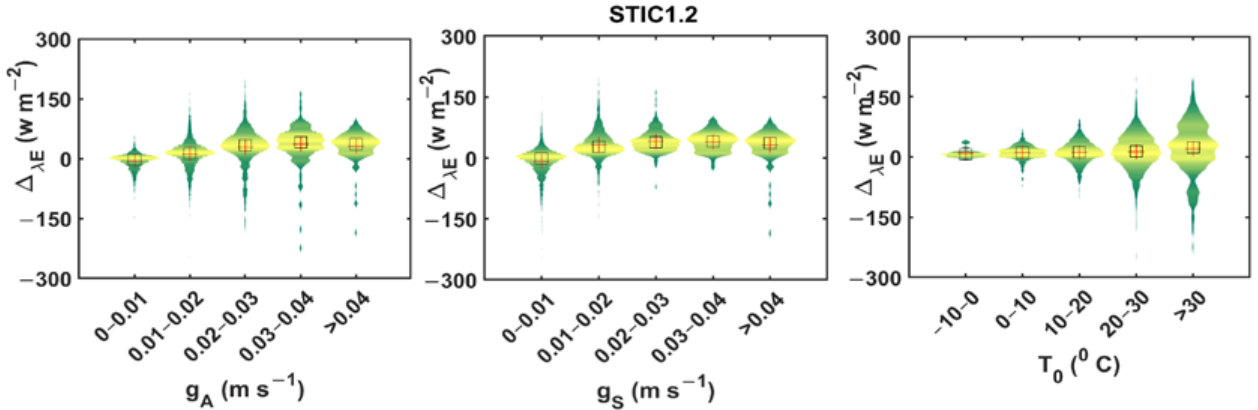

(c)

Figure 6. Box and violin plot showing the relationship between the residual errors in half-hourly $\lambda \mathrm{E}$ versus (a) simulated $g_{A}, g_{S}$ and $T_{C}$ in SCOPE1.7, (b) simulated $g_{A}, z_{0 M}$ and kB ${ }^{-1}$ in SEBS and (c) $g_{A}$, $\mathrm{g}_{\mathrm{S}}$, and $\mathrm{T}_{0}$ in STIC1.2.

Figure 6 revealed that $\Delta_{\lambda \mathrm{E}}$ from SCOPE1.7 $\left(\Delta_{\lambda \mathrm{E}} \mathrm{SCOPE} 1.7\right.$ hereafter) had a significantly positive relationship with the simulated canopy temperature $\left(\mathrm{T}_{\mathrm{c}}\right)(r=0.46, p$-value $<0.05)$, and a systematic overestimation of $\lambda \mathrm{E}\left(\Delta_{\lambda \mathrm{E}} \mathrm{SCOPE} 1.7\right.$ increased exponentially) with $\mathrm{T}_{\mathrm{C}}$ was evident when $\mathrm{T}_{\mathrm{c}}$ increased from 10 to $30^{\circ} \mathrm{C}$ (Figure 6a). However, $\Delta_{\lambda \mathrm{E}} \mathrm{SCOPE} 1.7$ was found to be moderately correlated $(r=0.22$ and $r=0.32$ for $\mathrm{g}_{\mathrm{A}}$ and $\mathrm{g}_{\mathrm{S}}$ respectively) with the two biophysical conductances (Figure 6a). The residual $\lambda E$ error from SEBS $\left(\Delta_{\lambda E}\right.$ SEBS hereafter) was inversely related to $g_{A}$ and $\mathrm{kB}^{-1}$ (Figure $6 \mathrm{~b}$ ). Here, a systematic underestimation of $\lambda \mathrm{E}$ was evident with increasing $\mathrm{g}_{\mathrm{A}}$ and $\mathrm{kB}^{-1}$ (Figure $6 \mathrm{~b}$ ) with a correlation of -0.55 and -0.27 ( $p$-value $<0.05$, significant), respectively. The mean residual $\lambda \mathrm{E}$ error from STIC1.2 ( $\Delta_{\lambda \mathrm{E}}$ STIC1.2 hereafter) showed an increasing pattern with an increase in $\mathrm{g}_{\mathrm{A}}$ and $\mathrm{g}_{\mathrm{S}}$ (Figure $6 \mathrm{c}$ ) having correlation of 0.35 and $0.27(p$-value $<0.05)$, respectively. However, $\Delta_{\lambda \mathrm{E}} \mathrm{STIC1} 1.2$ 
appeared to be heteroscedastic with an increase in $\mathrm{T}_{0}$, which signifies unequal variability of $\Delta_{\lambda \mathrm{E}} \mathrm{STIC1.2}$ as the value of $\mathrm{T}_{0}$ increases (Figure $6 \mathrm{c}$ ).

\subsection{Effects of Environmental and Ecohydrological Factors on the Model Performances}

Given the variable performance of the models to homogeneous inputs, this section described the role of environmental (meteorological and radiation) and surface $\left(\mathrm{T}_{\mathrm{S}}\right.$ and vegetation index) variables in determining the residual $\lambda \mathrm{E}$ error $\left(\Delta_{\lambda \mathrm{E}}=\right.$ predicted - observed $)$ of the individual models through principal component regression (PCR) analysis. This will be followed by assessing the role of general ecohydrological conditions on the weekly ET bias from the individual models.

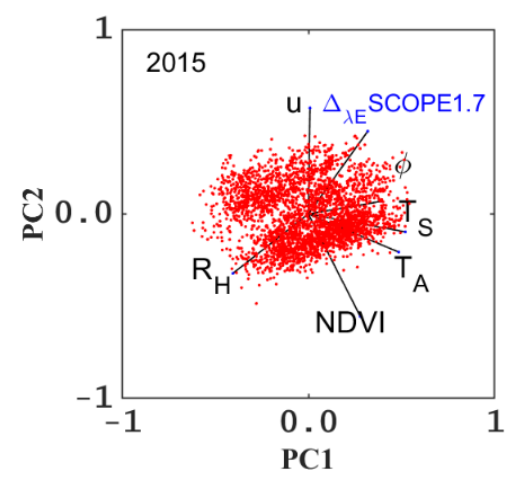

(a)

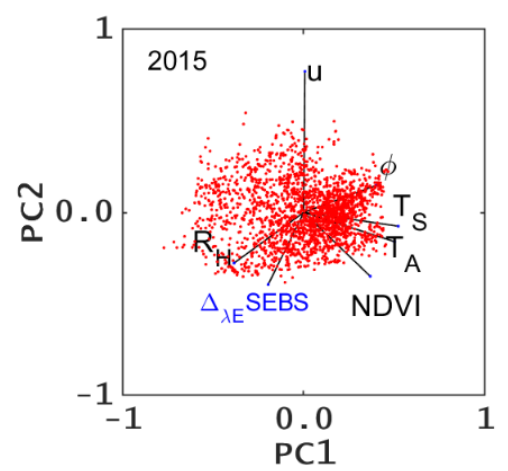

(c)

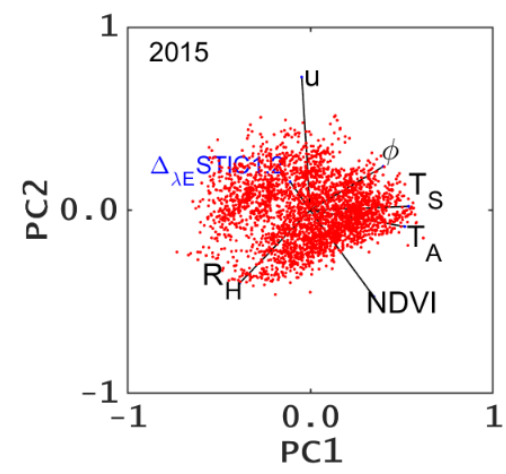

(e)

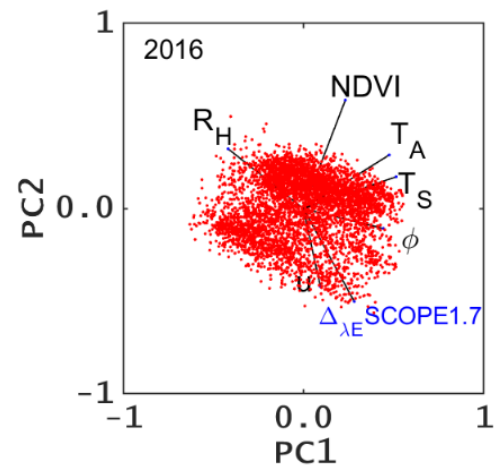

(b)

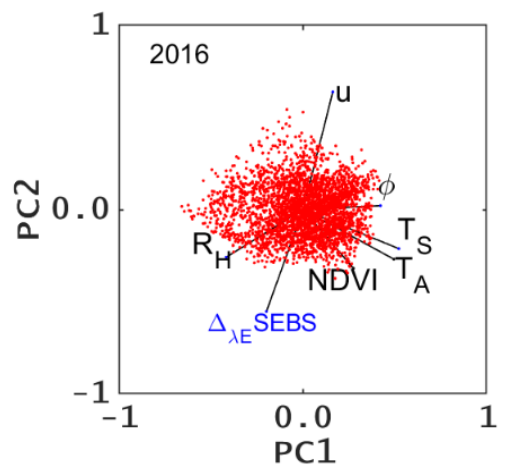

(d)

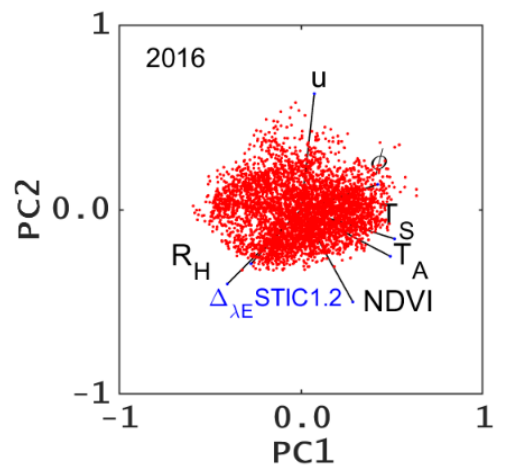

(f)

Figure 7. Loadings of Principal Component Regression (PCR) between residual errors simulated $\lambda \mathrm{E}$ with $\mathrm{T}_{\mathrm{S}}, \mathrm{NDVI}$, and environmental variables showing the contribution of each principal component in explaining the variance of the residual $\lambda$ E error in SCOPE1.7 (a,b), SEBS (c,d), and STIC1.2 (e,f), respectively, for years 2015 (left column) and 2016 (right column).

Principal component regression (PCR) of the residual model error $\left(\Delta_{\lambda E}\right)$ versus $T_{S}, T_{A}, \phi, R_{H}$, $\mathrm{u}$, and normalized difference vegetation index (NDVI) revealed $\mathrm{T}_{\mathrm{S}}, \mathrm{T}_{\mathrm{A}}, \phi$, to be the first principal 
component (PC1) whereas $R_{H}$ and $u$ to be the second principal component (PC2) affecting $\Delta_{\lambda \mathrm{E}}$ variance in all the three models in both the years (Figure 7). For all the models, the first principal components (PC1), which is on the horizontal axis, had positive coefficients for $\mathrm{T}_{\mathrm{S}}, \mathrm{T}_{\mathrm{A}}, \phi$, and $\mathrm{u}$ (exception SCOPE1.7 for year 2016 where $u$ had negative coefficient). Therefore, vectors are directed into the right half of the plot. It is also surprising to see that despite STIC1.2 was not driven by wind speed, there is an apparent relationship between $\Delta_{\lambda \mathrm{E}}$ and $\mathrm{u}$ in STIC1.2 due to a strong relationship between $\mathrm{u}$ and $\mathrm{T}_{\mathrm{S}}$. For all the models, maximum PC1 loading was found for $\mathrm{T}_{\mathrm{S}}$ and $\mathrm{T}_{\mathrm{A}}$ followed by $\phi$ (Figure 7) where their correlation with $\Delta_{\lambda \mathrm{E}}$ varied between $0.45-0.50$ (for $\left.\mathrm{T}_{\mathrm{S}}\right), 0.40-0.45\left(\mathrm{~T}_{\mathrm{A}}\right)$, and $0.30-0.40(\phi)$, respectively (Figure 7). Relatively high effects of wind speed $(\mathrm{u})$ on the $\Delta_{\lambda \mathrm{E}}$ variance were reflected in the second principal component axis (PC2) for SEBS (Figure 7b,c) followed by STIC1.2 and SCOPE1.7, with correlation varying from 0.40 to 0.60 .

An analysis on the impact of the ecohydrological conditions on the mean bias in weekly ET revealed a systematic underestimation of ET by SEBS $((-1)-(-12) \mathrm{mm} /$ week) for low range of soil moisture $\left(\theta<0.75 \mathrm{~m}^{3} \mathrm{~m}^{-3}\right)$, followed by a progressive overestimation of weekly ET $(2-3 \mathrm{~mm} /$ week $)$ with increasing $\theta\left(\theta>0.75 \mathrm{~m}^{3} \mathrm{~m}^{-3}\right)(\mathrm{r}=0.24, p$-value $<0.05)$ (Figure 8a). While SCOPE1.7 showed a general overestimation tendency in weekly ET across the entire range of soil moisture (2-8 mm/week), scatters of STIC1.2 revealed predominant underestimation of ET $(0-(-5) \mathrm{mm} /$ week) up to $\theta$ range of $0.7-0.8 \mathrm{~m}^{3} \mathrm{~m}^{-3}$ after which a moderate overestimation in weekly ET was noted (Figure $8 \mathrm{a}$ ). A consistent positive bias in weekly ET from SCOPE1.7 (2-8 mm/week) was evident with increasing climatological dryness $\left(E_{p} / P\right)$ with a significant correlation of 0.27 ( $p$-value $<0.05$ ) (Figure $8 b$ ); whereas ET underestimation tendency in SEBS was reduced with increasing $E_{p} / P$ ratio (Figure $8 b$ ). Contrarily, STIC1.2 showed an overestimation tendency in weekly ET (positive bias) $\left(2-6 \mathrm{~mm} /\right.$ week) for low $\mathrm{E}_{\mathrm{p}} / \mathrm{P}$ which progressively declined with increasing $\mathrm{E}_{\mathrm{p}} / \mathrm{P}$ ratio, with a correlation of 0.21 ( $p$-value $\left.<0.05\right)$.

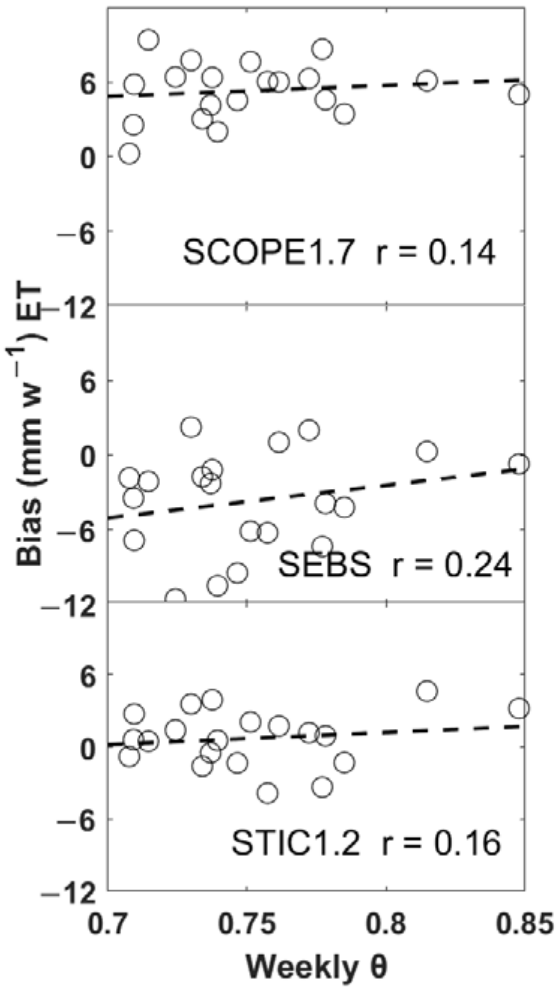

(a)

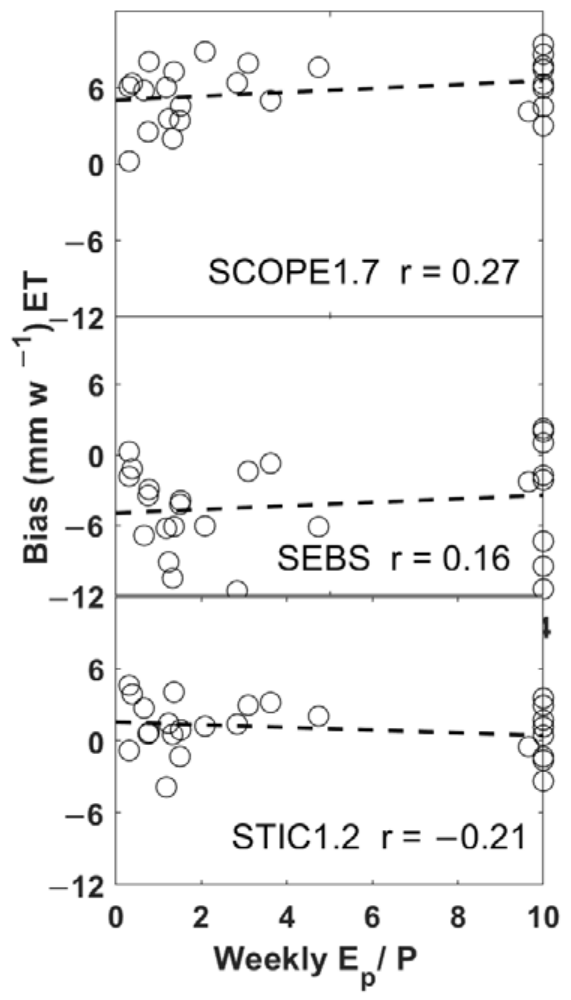

(b)

Figure 8. (a) Scatterplots of mean bias in weekly ET ( $\mathrm{mm} \mathrm{week}^{-1}$ ) simulated from STIC1.2, SCOPE1.7, and SEBS versus weekly soil moisture $(\theta)$, and $(\mathbf{b})$ Scatterplots of mean bias in weekly ET simulated from STIC1.2, SCOPE1.7, and SEBS versus weekly climatic aridity index ( $\mathrm{E}_{\mathrm{P}} / \mathrm{P}$ ratio). 


\section{Discussion}

\subsection{Effects of Model Structure and Biophysical Parameterizations on Residual $\lambda E$ or ET Errors}

Overall, STIC1.2 revealed marginal underestimation (negative mean bias) of half-hourly and daily $\lambda E$ and ET during both years (2015 and 2016), whereas SCOPE1.7 showed a tendency of overestimation and SEBS showed a tendency of underestimation especially in the beginning of the spring season. As evident from the residual error analysis, the underestimation tendency of STIC1.2 is due to the underestimation of $\lambda \mathrm{E}$ for the low values $\mathrm{g}_{\mathrm{A}}$ and $\mathrm{g}_{S}$ (Figure 6). Uncertainty in the relationship between thermal infrared temperature $\left(T_{S}\right)$ and aggregated moisture availability (M) in STIC1.2 could be a considerable source of underestimation of the conductances which is reflected in the simulation of $\lambda \mathrm{E}$ (and ET) through STIC1.2. In STIC1.2, M is modeled as a fraction of the dewpoint temperature difference between the evaporating front and atmosphere $\left(\mathrm{T}_{0 \mathrm{D}}-\mathrm{T}_{\mathrm{D}}\right)$ and of infrared temperature-dewpoint differences between surface to atmosphere $\left(\mathrm{T}_{\mathrm{S}}-\mathrm{T}_{\mathrm{D}}\right)$, weighted by two different slopes of saturation vapor pressure temperature relationships ( $\mathrm{s}_{1}$ and $\mathrm{s}_{2}$; equation S26 in [56], [M= $\left.s_{1}\left(T_{0 D}-T_{D}\right) / s_{2}\left(T_{S}-T_{D}\right)\right]$. The estimation of $T_{0 D}$ plays a critical role in the water unlimited wetland ecosystem because estimation of $\mathrm{T}_{0 \mathrm{D}}$ further requires sound estimation of $\mathrm{s}_{1}$. From the definition, $\mathrm{s}_{1}$ is the slope of the saturation vapor pressure versus temperature curve between the evaporating front and air $\left[\mathrm{s}_{1}=\left(\mathrm{e}_{0}-\mathrm{e}_{\mathrm{A}}\right) /\left(\mathrm{T}_{0 \mathrm{D}}-\mathrm{T}_{\mathrm{D}}\right)\right]$. However, in the wetland, $\mathrm{e}_{0}$ tends to approach saturation vapor pressure of wet surface and $s_{1}$ tend to be the slope of the wet surface to air saturation-vapor pressure versus temperature. In the present case, the estimates of $s_{1}$ as a function of air dewpoint temperature $\left(T_{D}\right)$ tend to be lower than the possible $s_{1}$-limits for the water-unlimited surfaces, which is likely to introduce underestimation errors in $\mathrm{T}_{0 \mathrm{D}}[56,57]$. Underestimation of $\mathrm{s}_{1}$ and $\mathrm{T}_{0 \mathrm{D}}$ would also lead to an underestimation of M (through the denominator in equation S26 in [56], thus leading to an underestimation of the conductances and $\lambda \mathrm{E}$. As demonstrated by [56], the ratio of $g_{S} / g_{A}$ increases with increasing $\mathrm{M}$ and the sensitivity of $g_{S}$ to $\mathrm{M}$ is substantially higher as compared to the sensitivity of $g_{A}$ to $\mathrm{M}$. An underestimation $\mathrm{M}$ would lead to an underestimation of $\mathrm{g}_{\mathrm{S}}$, and consequently an overestimation of the denominator [i.e., $\mathrm{s}+\gamma\left(1+\mathrm{g}_{\mathrm{A}} / \mathrm{g}_{\mathrm{S}}\right)$ ] in the Penman-Monteith equation (because $\mathrm{g}_{\mathrm{A}} / \mathrm{g}_{\mathrm{S}}$ in the denominator is overestimated). Thus underestimation errors could be introduced in $\lambda \mathrm{E}$ simulation in STIC1.2 for high soil moisture conditions.

In SEBS, the principal source of errors originated from consistent overestimation of $\mathrm{g}_{\mathrm{A}}$ (as seen in Figure 3a). The impact of $\mathrm{g}_{\mathrm{A}}$ and associated roughness length parameterization $\left(\mathrm{z}_{0 \mathrm{M}}\right.$ and $\left.\mathrm{kB}^{-1}\right)$ is therefore evident in the residual $\lambda E$ error in SEBS (Figure 6). In SEBS, $z_{0 M}$ is estimated as a function of the leaf area index and vegetation index [77], and low values of both the variables in the start of the growing season would tend to an underestimation of $\mathrm{z}_{0 \mathrm{M}}$, which would lead to an overestimation of $\mathrm{kB}^{-1}$ and $\mathrm{g}_{\mathrm{A}}$, and an underestimation of $\lambda \mathrm{E}$ (as see in Figure 6). Despite the strong dependence of $\mathrm{kB}^{-1}$ on $\mathrm{T}_{S}$, radiation, and meteorological variables [64]; no common consensus on a physically-based model for both $\mathrm{z}_{0 \mathrm{M}}$ and $\mathrm{kB}^{-1}$ is available $[67,68]$. Empirical parameterization of $\mathrm{z}_{0 \mathrm{M}}$ and $\pm 50 \%$ uncertainties in $z_{0 M}$ can also lead to $25 \%$ errors in $g_{A}$ estimation $[18,64,77]$, which would lead to more than $30 \%$ uncertainty in ET estimates. This is also evident from the semi-exponential pattern between $\mathrm{z}_{0 \mathrm{M}}$ and mean $\Delta_{\lambda E}$ SEBS (Figure $\left.6 b\right)$ that showed a positive correlation $(r=0.26, p$-value $<0.05$ ). Major $\lambda E$ differences for $\mathrm{kB}^{-1}$ range greater than 6 (typical range for the wet/saturated surfaces) (Figure 6b) indicates uncertainties in $\mathrm{kB}^{-1}$ parameterization for simulating $\lambda \mathrm{E}$ in the water-unlimited extremes. This is further reflected in the weekly ET bias versus soil moisture and $E_{p} / P$ scatters (Figure 8 ) where a negative bias was found for low values of soil moisture and $\mathrm{E}_{\mathrm{p}} / \mathrm{P}$ ratio, conditions that presumably exist in the start of the growing season.

Consistent underestimation of $\lambda \mathrm{E}$ at the start of the season (when the latent heat fluxes were generally low) is also associated with the structural uncertainties in SEBS in estimating the relative evaporation $\left(\Lambda_{\mathrm{r}}\right)$ which was estimated by scaling the actual sensible heat flux $(\mathrm{H})$ with the sensible heat fluxes for the driest $\left(\mathrm{H}_{\mathrm{dry}}\right)$ and wettest $\left(\mathrm{H}_{\mathrm{wet}}\right)$ conditions $\left[\Lambda_{\mathrm{r}}=1-\left(\mathrm{H}-\mathrm{H}_{\mathrm{wet}}\right) /\left(\mathrm{H}_{\mathrm{dry}}-\mathrm{H}_{\mathrm{wet}}\right)\right.$; and $\left.H_{d r y}=R n-G\right]$ [19]. In the start of the growing season (spring), when $\lambda E$ is low, any condition that 
produces $\mathrm{H} \approx \mathrm{H}_{\mathrm{dry}}$ would tend to simulate substantially low relative evaporation $\left(\Lambda_{\mathrm{r}} \approx 0\right)$, and $\lambda \mathrm{E}$ will be consequently underestimated (Figure 9a). As seen in Figure 9b, the residual daily ET error $\left(\Delta_{\mathrm{ET}}\right)$ in SEBS had a rather linear relationship with daily $\Lambda_{\mathrm{r}}(r=0.35-0.37, p$-value $<0.05)$ and a systematic underestimation in daily ET (up to $-\mathrm{mm} \mathrm{day}^{-1}$ ) was revealed for $0<\Lambda_{\mathrm{r}}<0.4$.

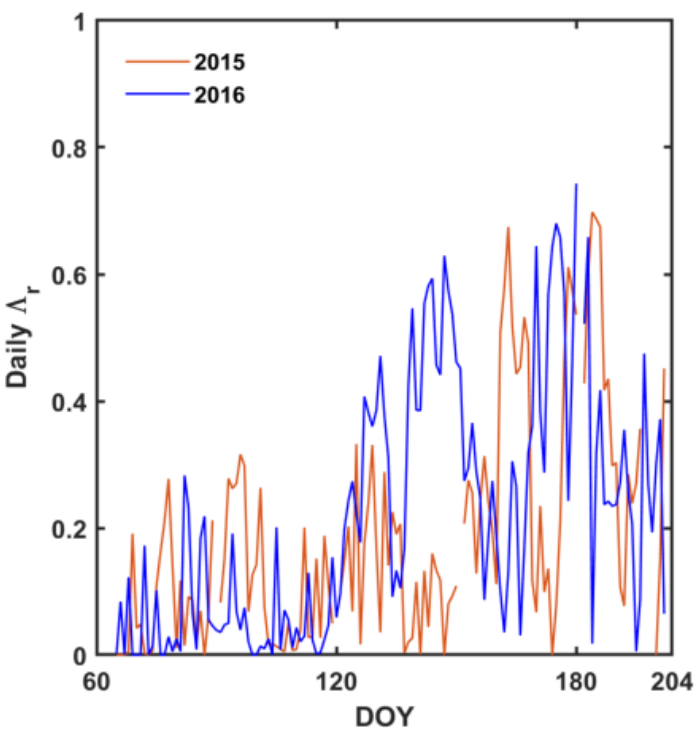

(a)

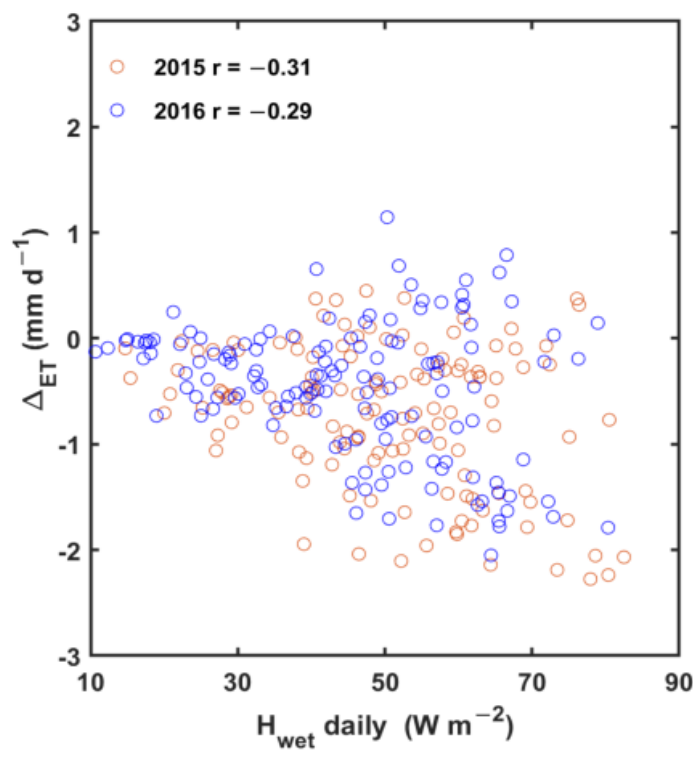

(c)

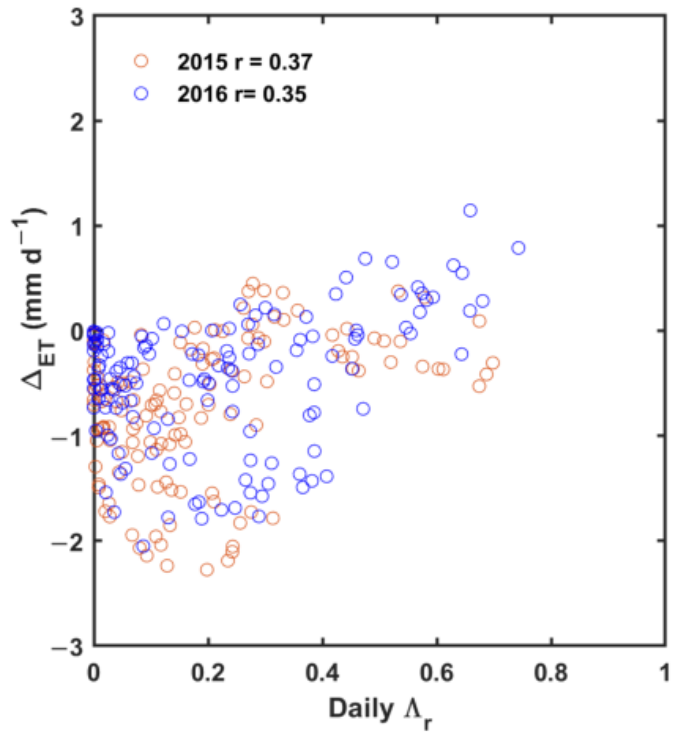

(b)

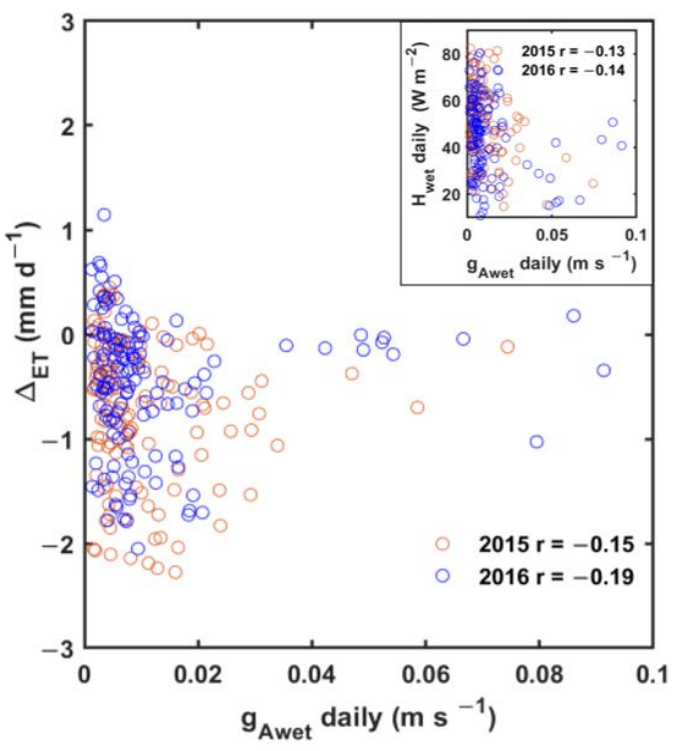

(d)

Figure 9. (a) Time-series of daily reference evaporation $\left(\Lambda_{r}\right)$ from SEBS for 2015 and 2016 which shows low magnitude of $\Lambda_{\mathrm{r}}$ in the beginning of the growing season where ET underestimation was predominant, (b) Scatterplots showing the relationship between residual error in daily ET ( $\left.\Delta_{\mathrm{ET}}\right)$ from SEBS with daily $\Lambda_{\mathrm{r}}$, which further confirms the systematic underestimation in ET was associated with estimation errors in $\Lambda_{\mathrm{r}}$, (c) Scatterplots showing the relationship between $\Delta_{\mathrm{ET}}$ from SEBS with simulated sensible heat flux for the wet limit $\left(\mathrm{H}_{\text {wet }}\right)$, (d) Scatterplots showing the relationship between $\Delta_{\mathrm{ET}}$ from SEBS with simulated aerodynamic conductance for the wet limit $\left(\mathrm{g}_{\text {Awet }}\right)$. Scatterplot in the inset shows the relationship between $\mathrm{H}_{\text {wet }}$ and $\mathrm{g}_{\text {Awet }}$.

Uncertainties in the estimation of wet limits of $\mathrm{H}$ (i.e., $\mathrm{H}_{\mathrm{wet}}$ ) and associated aerodynamic conductance in the wet limits $\left(\mathrm{g}_{\text {Awet }}\right.$ ) are also responsible for the systematic underestimation of 
$\lambda \mathrm{E}$ and ET in SEBS (Figure 9c,d). A consistent negative bias in daily ET was evident $(-1$ to -2 $\mathrm{mm} \mathrm{day}^{-1}$ ) for high magnitude of $\mathrm{H}_{\text {wet }}$ (Figure 9c) $[r=(-0.29)-(-0.31), p$-value $<0.05]$. This was mainly due to the inverse exponential relationship between $\mathrm{H}_{\text {wet }}$ and $\mathrm{g}_{\text {Awet }}$ (inset of Figure $9 \mathrm{~d}$ ) which was consequently propagated in ET as evident from the scatter between $\Delta_{\mathrm{ET}}$ versus $\mathrm{g}_{\text {Awet }}$ $[r=(-0.15)-(-0.19), p$-value $<0.05]$ (Figure 9d).

Like SEBS, $g_{A}$ estimation in SCOPE1.7 is also based on the Monin-Obukhov Similarity Theory and similar empirical sub-models for the roughness lengths $\left(\mathrm{z}_{0 \mathrm{M}}\right.$ and $\left.\mathrm{z}_{0 \mathrm{H}}\right)$ [58]. Therefore, the errors in $\lambda \mathrm{E}$ and ET in SCOPE1.7 due to large overestimation of $g_{\mathrm{A}}$ appear to be similar to SEBS. However, an additional source of uncertainty in SCOPE1.7 is due to a consistent overestimation of $\mathrm{g}_{\mathrm{S}}$ (Figure 3b) which was consequently propagated into overestimation of $\lambda \mathrm{E}$. In SCOPE1.7, $\mathrm{g}_{\mathrm{S}}$ parameterization is based on the Ball-Woodrow-Berry (BWB) gs-photosynthesis model [85]. BWB model was originally developed at the leaf-scale and no universally agreed scaling method is available to extrapolate this model for the ecosystem scale [86]. Photosynthesis simulation in SCOPE1.7 depends on the calibration of $\mathrm{V}_{\mathrm{cmax}}$ (i.e., maximum carboxylation capacity) [87], parameter for dark respiration, Extinction coefficient for vertical profile of $\mathrm{V}_{\mathrm{cmax}}$. Uncertainty in photosynthesis simulation in SCOPE1.7 would lead to erroneous $g_{S}$ (due to the $g_{S}$-photosynthesis feedback in the model) and $\lambda \mathrm{E}$. The major problem of using BWB or BWB-Leuning class of models is that they are valid only for saturated soil water conditions and cannot accommodate the soil drying process or when the soil drying is coupled with high atmospheric vapor pressure deficit. However, there are new generation $g_{S}$ models that could be used to predict stomatal conductance during soil dry-down when accounting for the soil-xylem hydraulics and detailed plant physiological attributes [88-91]. Assessing the photosynthesis related uncertainty in SCOPE1.7 is beyond the scope of this study, but, the consistent overestimation tendency in ET (Figure 8b) indicates the uncertainty in $\mathrm{g}_{S}$ and $\mathrm{g}_{\mathrm{A}}$ simulation (Figure 3) under high atmospheric aridity (high $\mathrm{E}_{\mathrm{P}}$ and low $\mathrm{P}$ ) (Figure 10 below) to be one of the main sources of errors in SCOPE1.7.

\subsection{Effects of Ecohydrological Conditions on Conductance Estimation and Implication on Model Performances}

To probe into the reasons for the weekly bias in ET versus $\theta$ and $\mathrm{E}_{\mathrm{p}} / \mathrm{P}$ ratio (as seen in Figure 8), the effects of ecohydrological conditions on the two biophysical conductance retrievals are presented in Figure 10, which showed the scatters between weekly $\mathrm{g}_{\mathrm{S}} / \mathrm{g}_{\mathrm{A}}$ ratio from STIC1.2 and SCOPE1.7 with weekly $\theta$ and $\mathrm{E}_{\mathrm{p}} / \mathrm{P}$ ratio. For STIC1.2, a weak and nearly invariant relationship $(r=0.02, p$-value $>$ 0.05 ) was found between $g_{S} / g_{A}$ ratio versus $\theta$ (Figure 10a). Since the soil moisture was predominantly high (to the level of saturation) in the UBNP wetland, the conductances retrieved through STIC1.2 appeared to be unaffected due the underlying soil moisture conditions. However, $g_{S} / g_{A}$ ratio from STIC1.2 progressively diminished with increasing $\mathrm{E}_{\mathrm{p}} / \mathrm{P}$ (Figure $10 \mathrm{~b}$ ) with a significant correlation $(r=0.64, p$-value $<0.05)$, which means low $\mathrm{g}_{\mathrm{S}}$ as compared to $\mathrm{g}_{\mathrm{A}}$ with increasing atmospheric aridity and evaporative demand. This further emphasizes the uncertainties due to surface moisture characterization in STIC1.2 especially the assumptions associated with the slope of temperature-vapor pressure relationship as described in Section 6.1. For SCOPE1.7, although $g_{S} / g_{A}$ ratio varied between 0.8-1.0 for the entire range of soil moisture, but, there was a significantly positive relationship $(r=$ $0.41, p$-value $<0.05)$ between SCOPE1.7-derived $\mathrm{g}_{\mathrm{S}} / \mathrm{g}_{\mathrm{A}}$ ratio with $\mathrm{E}_{\mathrm{p}} / \mathrm{P}$. This signifies relatively high values of $g_{S}$ (as compared to $g_{A}$ ) with increasing evaporative demand (and atmospheric aridity). The tendency of simulating high $\mathrm{g}_{S}$ as compared to $\mathrm{g}_{\mathrm{A}}$ with increasing evaporative demand (i.e., high $\mathrm{E}_{\mathrm{P}}$ ) was eventually propagated into an overestimation of $\lambda \mathrm{E}$ (and ET) in SCOPE1.7. With the progress of the growing season from spring onwards, an increase in the atmospheric vapor pressure deficit, air temperature and radiative load led to an increase in the evaporative demand of the atmosphere where $\lambda$ E overestimation (due to $g_{S}$ ) was predominant. 


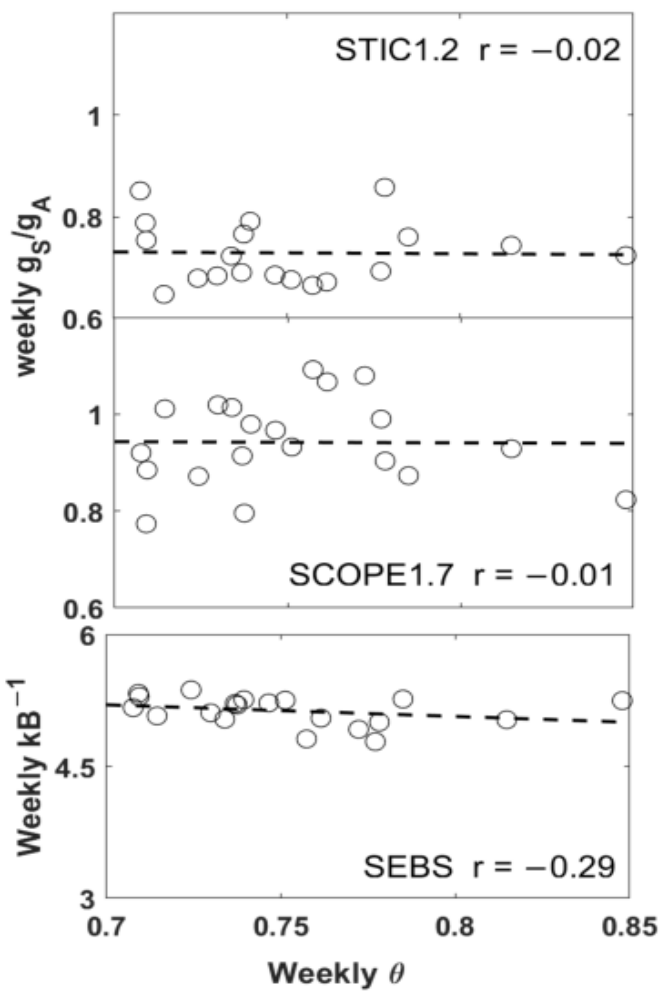

(a)

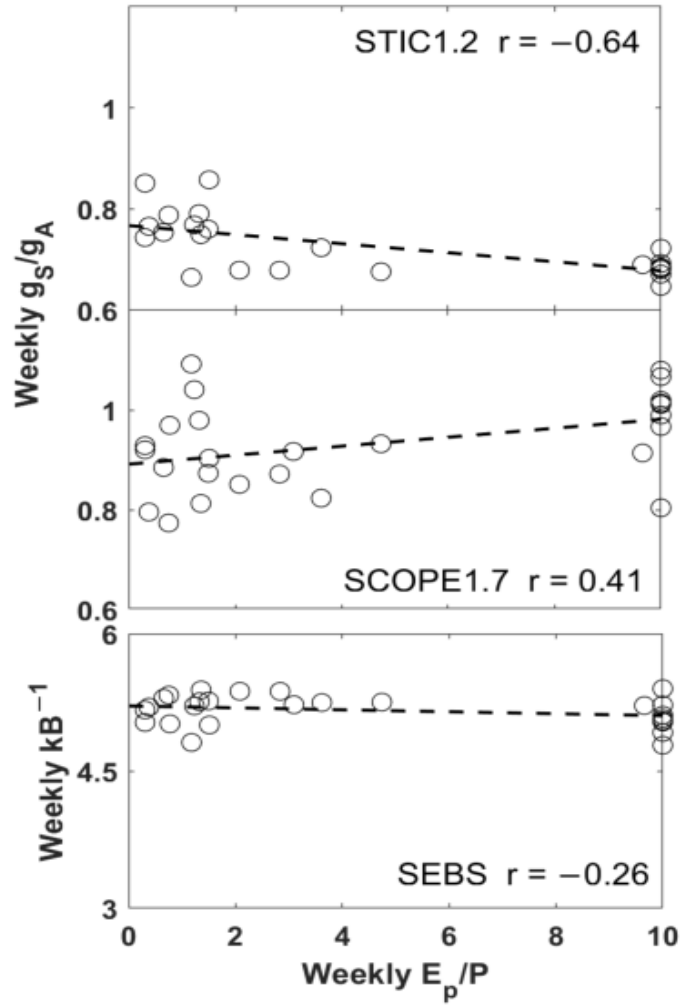

(b)

Figure 10. (a) Scatterplots of weekly $g_{S} / g_{A}$ ratio simulated from STIC1.2 and SCOPE1.7 $\left(\mathrm{kB}^{-1}\right.$ for SEBS) versus weekly soil moisture $(\theta)$, and $(\mathbf{b})$ weekly climatic aridity index ( $E_{\mathrm{P}} / \mathrm{P}$ ratio). Since SEBS does not simulate $\mathrm{g}_{\mathrm{A}}$, the behaviour of $\mathrm{kB}^{-1}$ was assessed with respect to the same ecohydrological conditions $\left(\theta\right.$ and $E_{P} / P$ ratio). This shows that $g_{S} / g_{A}$ ratio simulated through STIC1.2 and SCOPE1.7 was not affected by the soil moisture conditions, but it was strongly affected by $\mathrm{E}_{\mathrm{P}} / \mathrm{P}$ ratio. In SEBS, $\mathrm{kB}^{-1}$ was found to be affected by both $\theta$ and $\mathrm{E}_{\mathrm{P}} / \mathrm{P}$ ratio.

As discussed in Section 6.1, errors in the aerodynamic conductance in SEBS appears to be caused due to the empirical parameterizations of $\mathrm{z}_{0 \mathrm{M}}$ and $\mathrm{kB}^{-1}$ that is eventually propagated to $\mathrm{z}_{\mathrm{OH}}$ [77]. To further understand the role of general ecohydrological conditions on $\mathrm{g}_{\mathrm{A}}$ simulation and its impact on ET estimation in SEBS (SEBS does not simulate $\mathrm{g}_{\mathrm{S}}$ ), the scatterplots of weekly $\mathrm{kB}^{-1}$ versus weekly soil moisture and $E_{p} / P$ ratio are also showed in Figure 10 . This figure highlights a significant impact of these two ecohydrological factors on the estimation of $\mathrm{kB}^{-1}(r=-0.26$ to $-0.29, p$-value $<0.05)$. The prevailing soil moisture and $\mathrm{E}_{\mathrm{p}} / \mathrm{P}$ ratio in the UBNP wetland during the start of the spring typically varying between $0.7-0.8 \mathrm{~m}^{3} \mathrm{~m}^{-3}$ and $0-2$ and the underestimation tendency of SEBS is maximally noted in this range of soil moisture and $E_{p} / P$ ratio. Majority of the $\lambda \mathrm{E}(\mathrm{ET})$ underestimation was evident when $\mathrm{kB}^{-1}$ values exceeded 6 which is a typical range of $\mathrm{kB}^{-1}$ in the humid ecosystems with low $\mathrm{E}_{\mathrm{p}} / \mathrm{P}$ ratio (0-2), and the underestimation trend was consistent for $E_{P} / P$ ratio of $0-2$. Thus, underestimation of $z_{0 M}$ (due to low NDVI in the start of the growing season) in conjunction with an overestimation of $\mathrm{kB}^{-1}$ would lead to an underestimation of $\mathrm{z}_{0 \mathrm{H}}\left[\mathrm{z}_{0 \mathrm{H}}=\right.$ $\left.\mathrm{z}_{0 \mathrm{M}} / \exp \left(\mathrm{kB}^{-1}\right)\right]$. Underestimation of $\mathrm{z}_{\mathrm{OH}}$ consequently led to an overestimation of $\mathrm{g}_{\mathrm{A}}$ and $\mathrm{H}$ both for the actual and the wet limits, and a consistent underestimation of $\lambda E(E T)$ was discernible. Previous studies $([77,92])$ also revealed substantial uncertainties in $\mathrm{z}_{0 \mathrm{M}}$ and $\mathrm{kB}^{-1}$ that eventually led to uncertain estimation of ET. Our results demonstrated the critical role of surface to aerodynamic conductance parameterizations on the performance of the SVAT and SEB models.

It is also important to mention that significant differences were noted in the aerodynamic conductances simulated by the three models. The differences between $\mathrm{g}_{\mathrm{A}}$ from the models were 
mainly attributed to their structural differences and the nature of the parameterization of $g_{A}$ from all the three models. Therefore, the difference in $\mathrm{g}_{\mathrm{A}}$ estimates markedly contributed to the different statistical metric between simulated versus observed $\lambda \mathrm{E}$ (and ET) from the models. In general, the accuracies in commonly used parametric $g_{A}$ estimates based on wind speed and surface roughness parameters several meters distant from canopy foliage are limited due to the uncertainties related to the attenuation of wind speed close to the vegetation surface $[93,94]$. The wind speed close to the foliage can be substantially lower than that measured at some reference location above the vegetation canopy [95]. Notwithstanding the inequalities of $g_{A}$ estimated with different methods, inferring the accuracy of the different $g_{A}$ estimates is beyond the scope of the manuscript. However, $g_{A}$ is one of the main anchors in the SVAT and SEB models because it provides feedback to $g_{S}$ [96]. Therefore, ET estimation using SVAT and SEB models are very sensitive to $g_{A}$ and a universally agreed $g_{A}$ parameterization is needed to obtain similar $\lambda \mathrm{E}$ results from the models [97,98]. Given the lack of consensus in the community on the "true" $\mathrm{g}_{\mathrm{A}}$ and from the nature of surface flux validation results (Figure 4), it appears that $\mathrm{g}_{\mathrm{A}}$ from STIC1.2 tends to be the appropriate aerodynamic conductance that tend to produce the lowest $\lambda \mathrm{E}$ error.

\section{Conclusions}

This paper demonstrates the role of aerodynamic and canopy-surface (i.e., vegetation-substrate complex) conductance ( $g_{\mathrm{A}}$ and $\mathrm{g}_{\mathrm{S}}$ ) parameterizations in estimating ET from SVAT and SEB models. By using high temporal frequency eddy covariance measurements and three different SVAT and SEB models (SCOPE1.7, SEBS, and STIC1.2), we showed the critical role of ecohydrological conditions in influencing the conductance and latent heat flux simulation, and consequently daily ET. Independent validation of the models using observed latent heat flux data from an anomalous and a normal precipitation year (2015 and 2016) from one of the most ecologically important wetlands (Upper Biebrza National Park, Poland) (UBNP) led us to the following conclusions.

(a) Notable differences were found out in the $g_{A}$ and $g_{S}$ estimates from the three models. While SCOPE1.7 revealed substantial overestimation of both $\mathrm{g}_{\mathrm{A}}$ and $\mathrm{g}_{\mathrm{S}}$ with respect to the EC tower estimates, STIC1.2 derived $\mathrm{g}_{\mathrm{A}}$ and $\mathrm{g}_{S}$ were within the range of EC tower estimates. SEBS revealed a consistent overestimation of $\mathrm{g}_{\mathrm{A}}$ during the start of the growing season in spring, and $g_{A}$ estimates were is good agreement with the EC tower during the active vegetative phase in summer.

(b) All the models explained significant variability in the observed ET with a root mean square error (RMSE) of $0.4-1 \mathrm{~mm} \mathrm{day}^{-1}$ and mean absolute percent error (MAPE) of $16-44 \%$. Model intercomparison showed STIC1.2 to produce the least bias and good agreement with the observations, whereas SEBS and SCOPE1.7 revealed consistent underestimation and overestimation, respectively, in both years.

(c) Underestimation of $\lambda \mathrm{E}$ (and ET) in SEBS was mainly attributed to the underestimation in the roughness lengths of momentum and heat transfers $\left(\mathrm{z}_{0 \mathrm{M}}\right.$ and $\left.\mathrm{z}_{\mathrm{OH}}\right)$. While the underestimation of $\mathrm{z}_{0 \mathrm{M}}$ is associated with the empirical modeling structure, the underestimation of $\mathrm{z}_{0 \mathrm{H}}$ was associated with the overestimation of ' $\mathrm{kB}^{-1}$-term' under high soil moisture and low atmospheric aridity conditions. Underestimation of both $\mathrm{z}_{0 \mathrm{M}}$ and $\mathrm{z}_{0 \mathrm{H}}$ led to an overestimation of the aerodynamic conductance $\left(\mathrm{g}_{\mathrm{A}}\right)$ and sensible heat flux $(\mathrm{H})$, which was consequently reflected in the underestimation of ET.

(d) Although both SEBS and SCOPE1.7 had similar empirical parameterization of $\mathrm{g}_{\mathrm{A}}$, a consistent overestimation of $\lambda \mathrm{E}$ (and ET) in SCOPE1.7 was associated with the overestimation of the canopy-surface conductance $\left(\mathrm{g}_{\mathrm{S}}\right)$ under high atmospheric aridity and also presumably due to the gS-photosynthesis modeling uncertainty in SCOPE1.7 under high atmospheric vapor pressure deficit. 
(e) Despite all the three model captured substantial variability in $\lambda \mathrm{E}$ (and ET), the principal difference between the models appear to be associated with the differences in $g_{A}$ and $g_{S}$. Different magnitude $g_{A}$ and $g_{S}$ from all the models indicate the critical role of ambiguous parameterizations of these two important conductances for a broad spectrum of ecohydrological conditions. While SEBS require improved roughness length representation for enhancing the performance of $g_{A}$ sub-models under low fractional vegetation cover conditions; SCOPE1.7 requires robust parameterizations for both $g_{A}$ and $g_{S}$, and default calibration parameters prior to large-scale ET monitoring in the wetlands.

(f) The models showed promise as a quick and simple monitoring tool for wetland evapotranspiration. The simplified analytical model STIC1.2, requiring only surface-air temperature, humidity, and radiation data, can produce comparable results to more complex methods like SEBS under fully vegetated conditions and relatively better results under low fractional vegetation cover. Furthermore, this study demonstrated the model's potential for large scale ET mapping in the wetlands to capture the spatio-temporal ET dynamics. A dense network of radiation, temperature and humidity monitoring stations would also help create near-real time ET maps for the eco-hydrological studies in the Upper Biebrza National Park region.

Supplementary Materials: The following are available online at http:/ / www.mdpi.com/2073-4441/10/12/1753/ s1, Table S1: Table of symbols, their description and units used in the study, Table S2: Input variables and parameters of the SCOPE1.7 model.

Author Contributions: K.M. conceived the idea, planned the experiment and wrote the manuscript with the results generated by L.W.; L.W. performed the simulation and data analysis with the supervision of K.M.; J.C. and M.K. carried out the EC measurements and EC data processing. All the co-authors contributed through intellectual suggestions and edits in the manuscript.

Funding: This study was supported by HiWET consortium jointly funded by the Belgian Science Policy (BELSPO)-Fonds National de la Recherche (FNR)-Luxembourg under the program STEREOIII (INTER/STEREOIII/13/03/HiWET; CONTRACT NR SR/00/301). KM was also supported by the Luxembourg Institute of Science and Technology (LIST) through the project BIOTRANS (grant number 00001145) and CAOS-2 project grant (INTER/DFG/14/02) funded by FNR-DFG.

Acknowledgments: LW acknowledges the suggestions of Christiaan van der Tol of University of Twente in the initial version of the manuscript.

Conflicts of Interest: The authors declare no conflict of interest.

\section{References}

1. Sanderson, J.S.; Cooper, D.J. Ground Water Discharge by Evapotranspiration in Wetlands of an Arid Intermountain Basin. J. Hydrol. 2008, 351, 344-359. [CrossRef]

2. Oberg, W.J.; Melesse, M.A. Evapotranspiration Dynamics at an Ecohydrological Restoration Site: An Energy Balance and Remote Sensing Approach. J. Am. Water Resour. Assoc. 2007, 42, 565-582. [CrossRef]

3. Ceron, N.C.; Melesse, M.A.; Price, R.; Dessu, B.S.; Kandel, P.H. Operational Actual Wetland Evapotranspiration Estimation for South Florida Using MODIS Imagery. Remote Sens. 2015, 7, 3615-3632. [CrossRef]

4. Middleton, B.A.; Souter, J.N. Functional Integrity of Freshwater Forested Wetlands, Hydrologic Alteration, and Climate Change. Ecosyst. Heal. Sustain. 2016, 2, e01200. [CrossRef]

5. Middleton, B.A. Climate and Land-Use Change in Wetlands: A Dedication. Ecosyst. Heal. Sustain. 2017, 3, 1-2. [CrossRef]

6. Bastiaanssen, W.G.M.; Ahmad, M.; Chemin, Y. Satellite Surveillance of Evaporative Depletion across the Indus Basin. Water Resour. Res. 2002, 38, 1273. [CrossRef]

7. Siedlecki, M.; Pawlak, W.; Fortuniak, K.; Zieliński, M. Wetland Evapotranspiration: Eddy Covariance Measurement in the Biebrza Valley, Poland. Wetlands 2016, 36, 1055-1067. [CrossRef]

8. Sumner, D.; Clark, K. Measurement and Simulation of Evapotranspiration at a Wetland Site in the New Jersey Pinelands; U.S. Geological Survey: Reston, VA, USA, 2012. 
9. Stannard, D.I.; Gannett, M.W.; Polette, D.; Cameron, J.; Waibel, M.S.; Spears, J.M. Evapotranspiration from Marsh and Open-Water Sites at Upper Klamath Lake, Oregon, 2008-2010; U.S. Geological Survey: Reston, VA, USA, 2013.

10. Jacobs, J.M.; Mergelsberg, S.L.; Lopera, A.F.; Myers, D.A. Evapotranspiration from a Wet Prairie Wetland under Drought Conditions: Paynes Prairie Preserve, Florida, USA. Wetlands 2002, 22, 374-385. [CrossRef]

11. Whitfield, B.; Jacobs, J.M.; Judge, J. Intercomparison Study of the Land Surface Process Model and the Common Land Model for a Prairie Wetland in Florida. J. Hydrometeorol. 2006, 7, 1247-1258. [CrossRef]

12. Kalma, J.; McVicar, T.; McCabe, M. Estimating Land Surface Evaporation: A Review of Methods Using Remotely Sensed Surface Temperature Data. Surv. Geophys. 2008, 29, 421-469. [CrossRef]

13. Liou, Y.-A.; Kar, S.K. Evapotranspiration Estimation with Remote Sensing and Various Surface Energy Balance Algorithms-A Review. Energies 2014, 7, 2821-2849. [CrossRef]

14. Anderson, W.B.; Zaitchik, B.F.; Hain, C.R.; Anderson, M.C.; Yilmaz, M.T.; Mecikalski, J.; Schultz, L. Towards an Integrated Soil Moisture Drought Monitor for East Africa. Hydrol. Earth Syst. Sci. 2012, 16, 2893-2913. [CrossRef]

15. Kustas, W.P.; Norman, J.M. A Two-Source Approach for Estimating Turbulent Fluxes Using Multiple Angle Thermal Infrared Observations. Water Resour. Res. 1997, 33, 1495-1508. [CrossRef]

16. Kustas, W.P.; Anderson, M.C. Advances in Thermal Infrared Remote Sensing for Land Surface Modeling. Agric. For. Meteorol. 2009, 149, 2071-2081. [CrossRef]

17. Norman, J.M.; Kustas, W.P.; Humes, K.S. Source Approach for Estimating Soil and Vegetation Energy Fluxes in Observations of Directional Radiometric Surface Temperature. Agric. For. Meteorol. 1995, 77, 263-293. [CrossRef]

18. Liu, S.; Lu, L.; Mao, D.; Jia, L. Evaluating Parameterizations of Aerodynamic Resistance to Heat Transfer Using Field Measurements. Hydrol. Earth Syst. Sci. 2007, 11, 769-783. [CrossRef]

19. Su, Z. The Surface Energy Balance System (SEBS) for Estimation of Turbulent Heat Fluxes. Hydrol. Earth Syst. Sci. 2002, 6, 85-100. [CrossRef]

20. Troufleau, D.; Lhomme, J.P.; Monteny, B.; Vidal, A. Sensible Heat Flux and Radiometric Surface Temperature over Sparse Sahelian Vegetation. I. An Experimental Analysis of the KB-1 Parameter. J. Hydrol. 1997, 188-189, 815-838. [CrossRef]

21. Colaizzi, P.D.; Kustas, W.P.; Anderson, M.C.; Agam, N.; Tolk, J.A.; Evett, S.R.; Howell, T.A.; Gowda, P.H.; O'Shaughnessy, S.A. Two-Source Energy Balance Model Estimates of Evapotranspiration Using Component and Composite Surface Temperatures. Adv. Water Resour. 2012, 50, 134-151. [CrossRef]

22. Boegh, E.; Soegaard, H.; Thomsen, A. Evaluating Evapotranspiration Rates and Surface Conditions Using Landsat TM to Estimate Atmospheric Resistance and Surface Resistance. Remote Sens. Environ. 2002, 79, 329-343. [CrossRef]

23. Wallace, J.S.; Verhoef, A. Modelling Interactions in Mixed-Plant Communities: Light, Water and Carbon Dioxide. In Leaf developmentr and Canopy Growth; Sheffield Academic Press: Sheffield, UK, 2000; p. 250.

24. Gökmen, M.; Vekerdy, Z.; Verhoef, A.; Verhoef, W.; Batelaan, O.; van der Tol, C. Integration of Soil Moisture in SEBS for Improving Evapotranspiration Estimation under Water Stress Conditions. Remote Sens. Environ. 2012, 121, 261-274. [CrossRef]

25. Cleugh, H.A.; Leuning, R.; Mu, Q.; Running, S.W. Regional Evaporation Estimates from Flux Tower and MODIS Satellite Data. Remote Sens. Environ. 2007, 106, 285-304. [CrossRef]

26. Boulet, G.; Mougenot, B.; Lhomme, J.-P.; Fanise, P.; Lili-Chabaane, Z.; Olioso, A.; Bahir, M.; Rivalland, V.; Jarlan, L.; Merlin, O.; et al. The SPARSE Model for the Prediction of Water Stress and Evapotranspiration Components from Thermal Infra-Red Data and Its Evaluation over Irrigated and Rainfed Wheat. Hydrol. Earth Syst. Sci. 2015, 19, 4653-4672. [CrossRef]

27. Anderson, M.C.; Norman, J.M.; Diak, G.R.; Kustas, W.P.; Mecikalski, J.R. A Two-Source Time-Integrated Model for Estimating Surface Fluxes Using Thermal Infrared Remote Sensing. Remote Sens. Environ. 1997, 60, 195-216. [CrossRef]

28. Anderson, M.C.; Kustas, W.P.; Norman, J.M.; Hain, C.R.; Mecikalski, J.R.; Schultz, L.; González-Dugo, M.P.; Cammalleri, C.; D’Urso, G.; Pimstein, A.; et al. Mapping Daily Evapotranspiration at Field to Continental Scales Using Geostationary and Polar Orbiting Satellite Imagery. Hydrol. Earth Syst. Sci. 2011, 15, $223-239$. [CrossRef] 
29. Kiptala, K.J.; Mohamed, Y.; Mul, M.M.; Zaag, P. Mapping Evapotranspiration Trends Using MODIS and SEBAL Model in a Data Scarce and Heterogeneous Landscape in Eastern Africa. Water Resour. Res. 2013, 49, 8495-8510. [CrossRef]

30. Olioso, A.; Taconet, O.; Mehrez, B.; Nivoit, D.; Promayon, F.; Rahmoune, L. Estimation of Evapotranspiration Using SVAT Models and Surface IR Temperature. In Proceedings of the 1995 International Geoscience and Remote Sensing Symposium, "Quantitative Remote Sensing for Science and Applications", IGARSS '95, Firenze, Italy, 10-14 July 1995; Volume 1, pp. 516-518.

31. Su, Z.; McCabe, M.F.; Wood, E.F.; Su, Z.; Prueger, J.H. Modeling Evapotranspiration during SMACEX: Comparing Two Approaches for Local- and Regional-Scale Prediction. J. Hydrometeorol. 2005, 6, 910-922. [CrossRef]

32. Singh, R.; Kilic, A.; Irmak, S.; Martin, D. Application of SEBAL Model for Mapping Evapotranspiration and Estimating Surface Energy Fluxes in South-Central Nebraska. J. Irrig. Drain. Eng. 2008, 134, 273-285. [CrossRef]

33. Mitsch, W.J.; Gosselink, J.J. Wetlands, 4th ed.; Van Nostrand, R., Ed.; Wiley: New York, NY, USA, 2007.

34. Verhoeven, J.T.A. Wetlands in Europe: Perspectives for Restoration of a Lost Paradise. Ecol. Eng. 2014, 66, 6-9. [CrossRef]

35. Bullock, A.; Acreman, M. The Role of Wetlands in the Hydrological Cycle. Hydrol. Earth Syst. Sci. 2003, 7, 358-389. [CrossRef]

36. Fossey, M.; Rousseau, A.N.; Bullock, A.; Acreman, M. Assessing the Long-Term Hydrological Services Provided by Wetlands under Changing Climate Conditions: A Case Study Approach of a Canadian Watershed. J. Hydrol. 2016, 541, 1287-1302. [CrossRef]

37. Mao, X.F.; Cui, L.J. Reflecting the Importance of Wetland Hydrologic Connectedness: A Network Perspective. Procedia Environ. Sci. 2012, 13, 1315-1326. [CrossRef]

38. Acreman, M.C.; José, P. The Hydrology of the UK-A Study of Change. In Wetlands; Routledge: London, UK, 2000.

39. Acreman, M.C.; Harding, R.J.; Lloyd, C.R.; McNeil, D.D. Evaporation Characteristics of Wetlands: Experience from a Wetgrassland and a Reedbed Using Eddy Correlation Measurements. Hydrol. Earth Syst. Sci. 2003, 7, 11-21. [CrossRef]

40. Kossowska-Cezak, U.; Olszewski, K.; Przybylska, G. Klimat Kotliny Biebrzańskiej (Climate of the Biebrza Valley). Adv. Agric. Sci. Probl. 1991, 58, 119-160.

41. Burkett, V.; Kusler, J. Climate Change: Potential Impacts and Interactions in Wetlands of the United States. J. Am. Water Resour. Assoc. 2000, 36, 313-320. [CrossRef]

42. Erwin, K. Wetlands and Global Climate Change: The Role of Wetland Restoration in a Changing World. Wetl. Ecol. Manag. 2009, 17, 71-84. [CrossRef]

43. Grygoruk, M.; Batelaan, O.; Okruszko, T.; Mirosław-Świątek, D.; Chormański, J.; Rycharski, M. Groundwater Modelling and Hydrological System Analysis of Wetlands in the Middle Biebrza Basin BT-Modelling of Hydrological Processes in the Narew Catchment; Świątek, D., Okruszko, T., Eds.; Springer: Berlin/Heidelberg, Germany, 2011; pp. 89-109.

44. Wassen, M.J.; Okruszko, T.; Kardel, I.; Chormanski, J.; Swiatek, D.; Mioduszewski, W.; Bleuten, W.; Querner, E.P.; El Kahloun, M.; Batelaan, O.; et al. Eco-Hydrological Functioning of the Biebrza Wetlands. In Wetlands: Functioning, Biodiversity Conservation, and Restoration SE-13; Bobbink, R., Beltman, B., Verhoeven, J.A., Whigham, D., Eds.; Ecological Studies; Springer: Berlin/Heidelberg, Germany, 2006; Volume 191, pp. 285-310.

45. Chormański, J.; Batelaan, O. Application of the WetSpa Distributed Hydrological Model for Catchment with Significant Contribution of Organic Soil. Upper Biebrza Case Study. Ann. Wars. Univ. Life Sci. SGGW 2011, 43, 25-35.

46. Chormański, J.; Berezowski, T.; Okruszko, T.; Ignar, S. Hydrography and Hydrology of the Upper Biebrza Basin. Contemp. Probl. Manag. Environ. Prot. 2011, 7, 175-203.

47. Swiatek, D.; Chormanski, J. The Verification of the Numerical River Flow Model by Use of Remote Sensing. In Conference for Wetlands: Monitoring, Modelling and Management; CRC Press: Boca Raton, FL, USA, 2007; p. 173. 
48. De Doncker, L.; Troch, P.; Verhoeven, R.; Bal, K.; Meire, P.; Quintelier, J. Determination of the Manning Roughness Coefficient Influenced by Vegetation in the River Aa and Biebrza River. Environ. Fluid Mech. 2009, 9, 549-567. [CrossRef]

49. Van Loon, A.H.; Schot, P.P.; Griffioen, J.; Bierkens, M.F.P.; Batelaan, O.; Wassen, M.J. Throughflow as a Determining Factor for Habitat Contiguity in a Near-Natural Fen. J. Hydrol. 2009, 379, 30-40. [CrossRef]

50. Batelaan, O.; De Smedt, F. GIS-Based Recharge Estimation by Coupling Surface-Subsurface Water Balances. J. Hydrol. 2007, 337, 337-355. [CrossRef]

51. Anibas, C.; Fleckenstein, J.H.; Volze, N.; Buis, K.; Verhoeven, R.; Meire, P.; Batelaan, O. Transient or Steady-State? Using Vertical Temperature Profiles to Quantify Groundwater-Surface Water Exchange. Hydrol. Process. 2009, 23, 2165-2177. [CrossRef]

52. Turc, L. Estimation of Irrigation Water Requirements, Potential Evapotranspiration: A Simple Climatic Formula Evolved up to Date. Ann. Agron 1961, 12, 13-49.

53. Christiansen, J.E. Pan Evaporation and Evapotranspiration from Climatic Data. J. Irrig. Drain. Div. 1968, 94, 243-266.

54. Priestley, C.H.B.; Taylor, R.J. On the Assessment of Surface Heat Flux and Evaporation Using Large-Scale Parameters. Mon. Weather. Rev. 1972, 100, 81-92. [CrossRef]

55. Campbell, D.I.; Williamson, J.L. Evaporation from a Raised Peat Bog. J. Hydrol. 1997, 193, 142-160. [CrossRef]

56. Mallick, K.; Toivonen, E.; Trebs, I.; Boegh, E.; Cleverly, J.; Eamus, D.; Koivusalo, H.; Drewry, D.; Arndt, K.; Griebel, A.; et al. Bridging Thermal Infrared Sensing and Physically-Based Evapotranspiration Modeling: From Theoretical Implementation to Validation Across an Aridity Gradient in Australian Ecosystems. Water Resour. Res. 2018, 54, 3409-3435. [CrossRef]

57. Mallick, K.; Trebs, I.; Boegh, E.; Giustarini, L.; Schlerf, M.; Drewry, D.; Hoffmann, L.; von Randow, C.; Kruijt, B.; Araùjo, A.; et al. Canopy-Scale Biophysical Controls of Transpiration and Evaporation in the Amazon Basin. Hydrol. Earth Syst. Sci. 2016, 20, 4237-4264. [CrossRef]

58. Van der Tol, C.; Verhoef, W.; Timmermans, J.; Verhoef, A.; Su, Z. An Integrated Model of Soil-Canopy Spectral Radiances, Photosynthesis, Fluorescence, Temperature and Energy Balance. Biogeosciences 2009, 6, 3109-3129. [CrossRef]

59. Verhoef, W. Light Scattering by Leaf Layers with Application to Canopy Reflectance Modeling: The SAIL Model. Remote Sens. Environ. 1984, 16, 125-141. [CrossRef]

60. Feret, J.-B.; François, C.; Asner, G.P.; Gitelson, A.A.; Martin, R.E.; Bidel, L.P.R.; Ustin, S.L.; le Maire, G.; Jacquemoud, S. PROSPECT-4 and 5: Advances in the Leaf Optical Properties Model Separating Photosynthetic Pigments. Remote Sens. Environ. 2008, 112, 3030-3043. [CrossRef]

61. Verhoef, W. Bayesian Optimisation Approach for Model Inversion of Hyperspectral-Multidirectional Observations: The Balance with A Priori Information. In Proceedings of the ISPRS 2007 10th International Symposium on Physical Measurements and Signatures Remote Sensing, Davos, Switzerland, 12-14 March 2017.

62. Su, Z.; Schmugge, T.; Kustas, W.P.; Massman, W.J. An Evaluation of Two Models for Estimation of the Roughness Height for Heat Transfer between the Land Surface and the Atmosphere. J. Appl. Meteorol. 2001, 40, 1933-1951. [CrossRef]

63. Anderson, M.C.; Allen, R.G.; Morse, A.; Kustas, W.P. Use of Landsat Thermal Imagery in Monitoring Evapotranspiration and Managing Water Resources. Remote Sens. Environ. 2012, 122, 50-65. [CrossRef]

64. Verhoef, A.; McNaughton, K.G.; Jacobs, A.F.G. A Parameterization of Momentum Roughness Length and Displacement Height for a Wide Range of Canopy Densities. Hydrol. Earth Syst. Sci. 1997, 1, 81-91. [CrossRef]

65. Faivre, R.; Colin, J.; Menenti, M. Evaluation of Methods for Aerodynamic Roughness Length Retrieval from Very High-Resolution Imaging LIDAR Observations over the Heihe Basin in China. Remote Sens. 2017, 9, 63. [CrossRef]

66. Kanda, M.; Kanega, M.; Kawai, T.; Moriwaki, R.; Sugawara, H. Roughness Lengths for Momentum and Heat Derived from Outdoor Urban Scale Models. J. Appl. Meteorol. Clim. 2007, 46, 1067-1079. [CrossRef]

67. Paul, G.; Gowda, P.; Prasad, P.V.V.; Howell, T.; Aiken, R.; Neale, C. Investigating the Influence of Roughness Length for Heat Transport (Zoh) on the Performance of SEBAL in Semi-Arid Irrigated and Dryland Agricultural Systems. J. Hydrol. 2013, 509, 231-244. [CrossRef] 
68. Rigden, A.; Li, D.; Salvucci, G. Dependence of Thermal Roughness Length on Friction Velocity across Land Cover Types: A Synthesis Analysis Using AmeriFlux Data. Agric. For. Meteorol. 2018, 249, 512-519. [CrossRef]

69. Ershadi, A.; McCabe, M.F.; Evans, J.P.; Wood, E.F. Impact of Model Structure and Parameterization on Penman-Monteith Type Evaporation Models. J. Hydrol. 2015, 525, 521-535. [CrossRef]

70. Ershadi, A.; McCabe, M.F.; Evans, J.P.; Chaney, N.W.; Wood, E.F. Multi-Site Evaluation of Terrestrial Evaporation Models Using FLUXNET Data. Agric. For. Meteorol. 2014, 187, 46-61. [CrossRef]

71. Long, D.; Singh, V.P.; Li, Z.-L. How Sensitive Is SEBAL to Changes in Input Variables, Domain Size and Satellite Sensor? J. Geophys. Res. Atmos. 2011, 116, D21107. [CrossRef]

72. Long, D.; Singh, V.P. A Two-Source Trapezoid Model for Evapotranspiration (TTME) from Satellite Imagery. Remote Sens. Environ. 2012, 121, 370-388. [CrossRef]

73. Petropoulos, G.; Carlson, T.N.; Wooster, M.J. An Overview of the Use of the SimSphere Soil Vegetation Atmosphere Transfer (SVAT) Model for the Study of Land-Atmosphere Interactions. Sensors 2009, 9, 4286-4308. [CrossRef] [PubMed]

74. Matheny, A.M.; Bohrer, G.; Stoy, P.C.; Baker, I.T.; Black, A.T.; Desai, A.R.; Dietze, M.C.; Gough, C.M.; Ivanov, V.Y.; Jassal, R.S.; et al. Characterizing the Diurnal Patterns of Errors in the Prediction of Evapotranspiration by Several Land-Surface Models: An NACP Analysis. J. Geophys. Res. Biogeosci. 2014, 119, 1458-1473. [CrossRef]

75. Baldocchi, D.; Ma, S. How Will Land Use Affect Air Temperature in the Surface Boundary Layer? Lessons Learned from a Comparative Study on the Energy Balance of an Oak Savanna and Annual Grassland in California, USA. Tellus B Chem. Phys. Meteorol. 2013, 65, 19994. [CrossRef]

76. Monteith, J.L. Accommodation between Transpiring Vegetation and the Convective Boundary Layer. J. Hydrol. 1995, 166, 251-263. [CrossRef]

77. Bhattarai, N.; Mallick, K.; Brunsell, N.A.; Sun, G.; Jain, M. Regional Evapotranspiration from an Image-Based Implementation of the Surface Temperature Initiated Closure (STIC1.2) Model and Its Validation across an Aridity Gradient in the Conterminous US. Hydrol. Earth Syst. Sci. 2018, 22, 2311-2341. [CrossRef]

78. Jacquemoud, S.; Verhoef, W.; Baret, F.; Bacour, C.; Zarco-Tejada, P.J.; Asner, G.P.; François, C.; Ustin, S.L. PROSPECT + SAIL Models: A Review of Use for Vegetation Characterization. Remote Sens. Environ. 2009, 113 (Suppl. 1), S56-S66. [CrossRef]

79. Wassen, M.J.; Barendregt, A.; Palczynski, A.; De Smidt, J.T.; De Mars, H. Hydro-Ecological Analysis of the Biebrza Mire (Poland). Wetl. Ecol. Manag. 1992, 2, 119-134. [CrossRef]

80. Bootsma, M.C.; Wassen, M.J.; Jansen, A.J.M. The Biebrza-Valley as an Ecological Reference for Dutch Stream Valleys. Landscape 2000, 17, 113-117.

81. Aber, J.D.; Melillo, J.M. Nitrogen Immobilization in Decaying Hardwood Leaf Litter as a Function of Initial Nitrogen and Lignin Content. Can. J. Bot. 1982, 60, 2263-2269. [CrossRef]

82. Dawson, T.E.; Burgess, S.S.O.; Tu, K.P.; Oliveira, R.S.; Santiago, L.S.; Fisher, J.B.; Simonin, K.A.; Ambrose, A.R. Nighttime Transpiration in Woody Plants from Contrasting Ecosystems. Tree Physiol. 2007, 27, 561-575. [CrossRef] [PubMed]

83. Chávez, J.L.; Neale, C.M.U.; Prueger, J.H.; Kustas, W.P. Daily Evapotranspiration Estimates from Extrapolating Instantaneous Airborne Remote Sensing ET Values. Irrig. Sci. 2008, 27, 67-81. [CrossRef]

84. Donohue, R.J.; McVicar, T.R.; Roderick, M.L. Assessing the Ability of Potential Evaporation Formulations to Capture the Dynamics in Evaporative Demand within a Changing Climate. J. Hydrol. 2010, 386, 186-197. [CrossRef]

85. Ball, J.T.; Woodrow, I.E.; Berry, J.A. A Model Predicting Stomatal Conductance and Its Contribution to the Control of Photosynthesis under Different Environmental Conditions BT-Progress in Photosynthesis Research: Volume 4 Proceedings of the VIIth International Congress on Photosynthesis Providence; Biggins, J., Ed.; Springer: Dordrecht, The Netherlands, 1987; pp. 221-224.

86. Bonan, G.; Williams, M.; Fisher, R.; Oleson, K. Modeling Stomatal Conductance in the Earth System: Linking Leaf Water-Use Efficiency and Water Transport along the Soil-plant-atmosphere Continuum. Geosci. Model Dev. 2014, 7, 2193. [CrossRef]

87. Rogers, A.; Medlyn, B.E.; Dukes, J.S. Improving Representation of Photosynthesis in Earth System Models. New Phytol. 2014, 204, 12-14. [CrossRef] [PubMed] 
88. Wolf, A.; Anderegg, W.R.L.; Pacala, S.W. Optimal Stomatal Behavior with Competition for Water and Risk of Hydraulic Impairment. Proc. Natl. Acad. Sci. USA 2016, 113, E7222-E7230. [CrossRef] [PubMed]

89. Huang, C.; Domec, J.; Ward, E.J.; Duman, T.; Manoli, G.; Parolari, A.J.; Katul, G.G. The Effect of Plant Water Storage on Water Fluxes within the Coupled Soil-plant System. New Phytol. 2017, 213, 1093-1106. [CrossRef] [PubMed]

90. Nikinmaa, E.; Hölttä, T.; Hari, P.; Kolari, P.; Mäkelä, A.; Sevanto, S.; Vesala, T. Assimilate Transport in Phloem Sets Conditions for Leaf Gas Exchange. Plant. Cell Environ. 2012, 36, 655-669. [CrossRef] [PubMed]

91. Sperry, J.S.; Venturas, M.D.; Anderegg, W.R.L.; Mencuccini, M.; Mackay, D.S.; Wang, Y.; Love, D.M. Predicting Stomatal Responses to the Environment from the Optimization of Photosynthetic Gain and Hydraulic Cost. Plant. Cell Environ. 2016, 40, 816-830. [CrossRef] [PubMed]

92. Timmermans, J.; Su, Z.; van der Tol, C.; Verhoef, A.; Verhoef, W. Quantifying the Uncertainty in Estimates of Surface-atmosphere Fluxes through Joint Evaluation of the SEBS and SCOPE Models. Hydrol. Earth Syst. Sci. 2013, 17, 1561-1573. [CrossRef]

93. Prihodko, L.; Denning, A.S.; Hanan, N.P.; Baker, I.; Davis, K. Sensitivity, Uncertainty and Time Dependence of Parameters in a Complex Land Surface Model. Agric. For. Meteorol. 2008, 148, 268-287. [CrossRef]

94. Meinzer, F.C.; Andrade, J.L.; Goldstein, G.; Holbrook, N.M.; Cavelier, J.; Jackson, P. Control of Transpiration from the Upper Canopy of a Tropical Forest: The Role of Stomatal, Boundary Layer and Hydraulic Architecture Components. Plant. Cell Environ. 2008, 20, 1242-1252. [CrossRef]

95. Meinzer, F.C.; Hinckley, T.M.; Ceulemans, R. Apparent Responses of Stomata to Transpiration and Humidity in a Hybrid Poplar Canopy. Plant. Cell Environ. 2008, 20, 1301-1308. [CrossRef]

96. Jarvis, P.G.; Mcnaughton, K. Stomatal Control of Transpiration: Scaling up from Leaf to Region. Adv. Ecol. Res. 1986, 15, 1-49.

97. Van Dijk, A.I.J.M.; Gash, J.H.; van Gorsel, E.; Blanken, P.D.; Cescatti, A.; Emmel, C.; Gielen, B.; Harman, I.N.; Kiely, G.; Merbold, L.; et al. Rainfall Interception and the Coupled Surface Water and Energy Balance. Agric. For. Meteorol. 2015, 214-215, 402-415. [CrossRef]

98. Holwerda, F.; Bruijnzeel, L.A.; Scatena, F.N.; Vugts, H.F.; Meesters, A.G.C.A. Wet Canopy Evaporation from a Puerto Rican Lower Montane Rain Forest: The Importance of Realistically Estimated Aerodynamic Conductance. J. Hydrol. 2012, 414-415, 1-15. [CrossRef] 